\title{
To Discover a New Tomorrow
}

by

Angela Chiesa

A thesis submitted to the Faculty of Graduate and Postdoctoral Affairs in partial

fulfilment of the requirements for the degree of

Master of Architecture

$\ln$

Azrieli School of Architecture \& Urbanism

Carleton University

Ottawa, Ontario

(C)2020 Angela Chiesa 


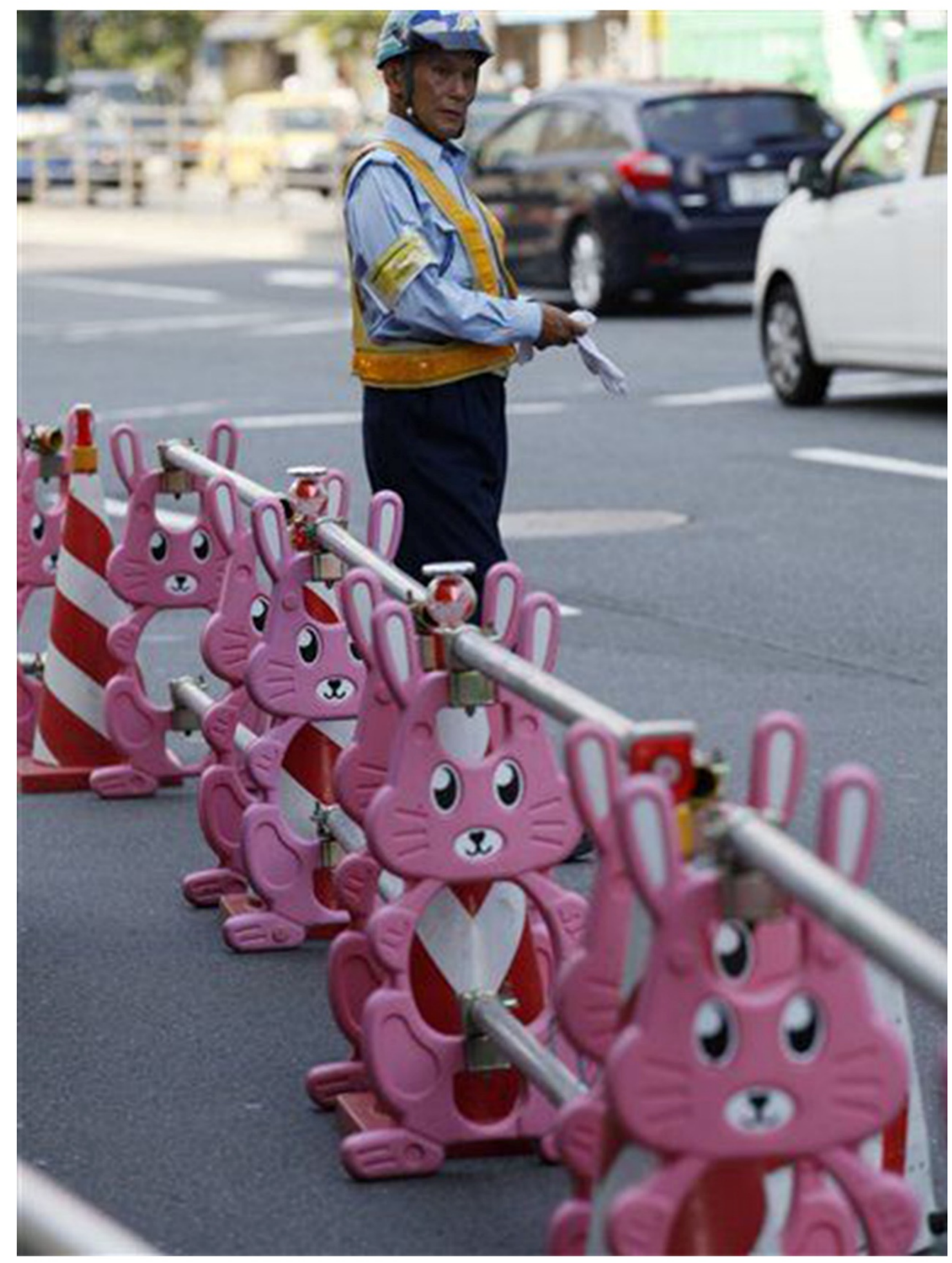




\section{Abstract}

Fig. 1. This thesis aims to critique the financial waste that is a result of the Tokyo 2020 Olympic Japanese Kawaii Pylons. Games. The project proposes a hypothetical underground Bank for money laundering which would use government money and turn it into profit for individual and corporate investors.

The research examines how Tokyo will host the 2020 Summer Olympic Games, speculates on how the Government of Japan intends to spend funds allocated for the Games and how the government and major corporations might mismanage or misuse these large sums of money.

The thesis is a series of annotated images that describe this hypothetical narrative. It shows the perspectives of a series of characters through the city, in order to reveal some of the harsh realities that come with hosting the Olympics. By using a researchby-design methodology, the thesis explores the front and back-of house relationship of the project, site and people that are integral to the Olympics. 
To Discover A New Tomorrow

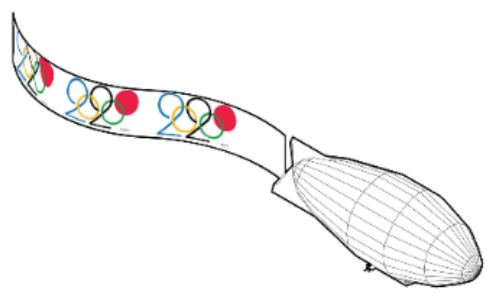




\section{Acknowledgements}

Fig. 2. I would like to express my deepest gratitude to Professor Johan Voordouw and Dr. Let the Olympics Begin!.

Ozayr Saloojee as my advisors for this thesis.

I thank Professor Johan Voordouw for his guidance, critical thinking, and especially, his time given not only as an advisor, but as a mentor. As both a professor and thesis advisor, Johan has largely influenced my academic career, for which I thank him for his dedication and patience.

To Dr. Ozayr Saloojee, I extend my sincerest appreciation for his critical feedback and valuable suggestions. His insight and words of encouragement have been crucial to the development of this thesis. 


\section{Contents}

$\begin{array}{ll}\text { Abstract } & 3\end{array}$

Acknowledgements

Table of Contents $\quad 6$

$\begin{array}{ll}\text { List of Figures } & 8\end{array}$

Preface to COVID-19 11

$\begin{array}{ll}\text { Preface to Narrative } & 15\end{array}$

$\begin{array}{ll}\text { Introduction } & 19\end{array}$

$\begin{array}{ll}\text { Site } & 23\end{array}$

$\begin{array}{ll}\text { Site Photos } & 26\end{array}$

Olympic Games 31

Tokyo $2020 \quad 37$

$\begin{array}{ll}\text { Project Narrative } & 41\end{array}$

$\begin{array}{ll}\text { Threshold } & 44\end{array}$

$\begin{array}{ll}\text { Money Collection } & 47\end{array}$ 
Tokyo 2020

$\begin{array}{ll}\text { Money Laundering } & 48\end{array}$

$\begin{array}{ll}\text { Vault } & 49\end{array}$

Design Process $\quad 51$

Drawing Process $\quad 54$

Conclusion $\quad 56$

$\begin{array}{ll}\text { Postscript } & 58\end{array}$

$\begin{array}{ll}\text { References } & 60\end{array}$ 


\section{List of Figures}

Fig. 1: Japan Today. Accessed January 22,

2020.https://japantoday.com/category/picture-of-the-day/bunny-barrier.

Fig. 2: Angela Chiesa, Let the Olympics Begin, 2019.

Fig. 3: Daily Mail. Accessed March 31, 2020, https://www.dailymail.co.uk/sport/article2256549/Olympic-Stadium-open-2013-stage-rock-concerts.html.

Fig. 4: Lim, CJ. Inhabitable Infrastructure. New York: Routledge, 2017.

Fig. 5: Lai, Jimenez. Citizens of No Place: An Architectural Graphic Novel. New York: Princeton Architectural Press, 2012.

Fig. 6: Angela Chiesa, Olympics for Profit, 2019.

Fig. 7: Angela Chiesa, Olympic Site Proposal, 2019.

Fig. 8: Angela Chiesa, Site Location, 2019.

Fig. 9: Angela Chiesa, Site Location in Plan, 2020.

Fig. 10: Kydo News. Accessed November 14, 2019. https://www.alamy.com/a-view-ofthe-proposed-site-of-athlete-village-for-the-2020-tokyo-image159089445.html. 26 
Fig. 11: Nippon. Accessed November 16. 2019.

https://www.nippon.com/en/jip/p00036/an-eye-to-the-future-tokyo-2020-olympic-

village-under-construction-japan-in-photos.html.

Fig. 12: Kydo News. Accessed November 14, 2019.

https://english.kyodonews.net/news/2018/07/3f59ddb7c0d1-olympics-tokyo-2020main-stadium-construction-site-opened-to-press.html?phrase=warmbier\&words=. 27

Fig. 13: Kydo News. Accessed November 14, 2019. https://www.alamy.com/a-view-ofthe-proposed-site-of-athlete-village-for-the-2020-tokyo-image159089445.html. 27

Fig. 14: Tomoyuki Tanaka, X-Ray Illustrations of Tokyo Train Stations, Pencil.

https://www.wired.com/2016/07/lose-tomoyuki-tanakas-x-ray-illustrations-tokyo-trainstations/.

Fig. 15: Angela Chiesa, Olympic Win, 2019.

Fig. 16: Angela Chiesa, Financial Data, 2019.

Fig. 17: Angela Chiesa, Tokyo's Regeneration Plan-Part 1, 2019.

Fig. 18: Angela Chiesa, Tokyo's Regeneration Plan - Part 2, 2019.

Fig. 19: Angela Chiesa, Narrative Introduction, 2019.

Fig. 20: Angela Chiesa, Characters, 2019.

Fig. 21: Angela Chiesa, Vault, 2019. 


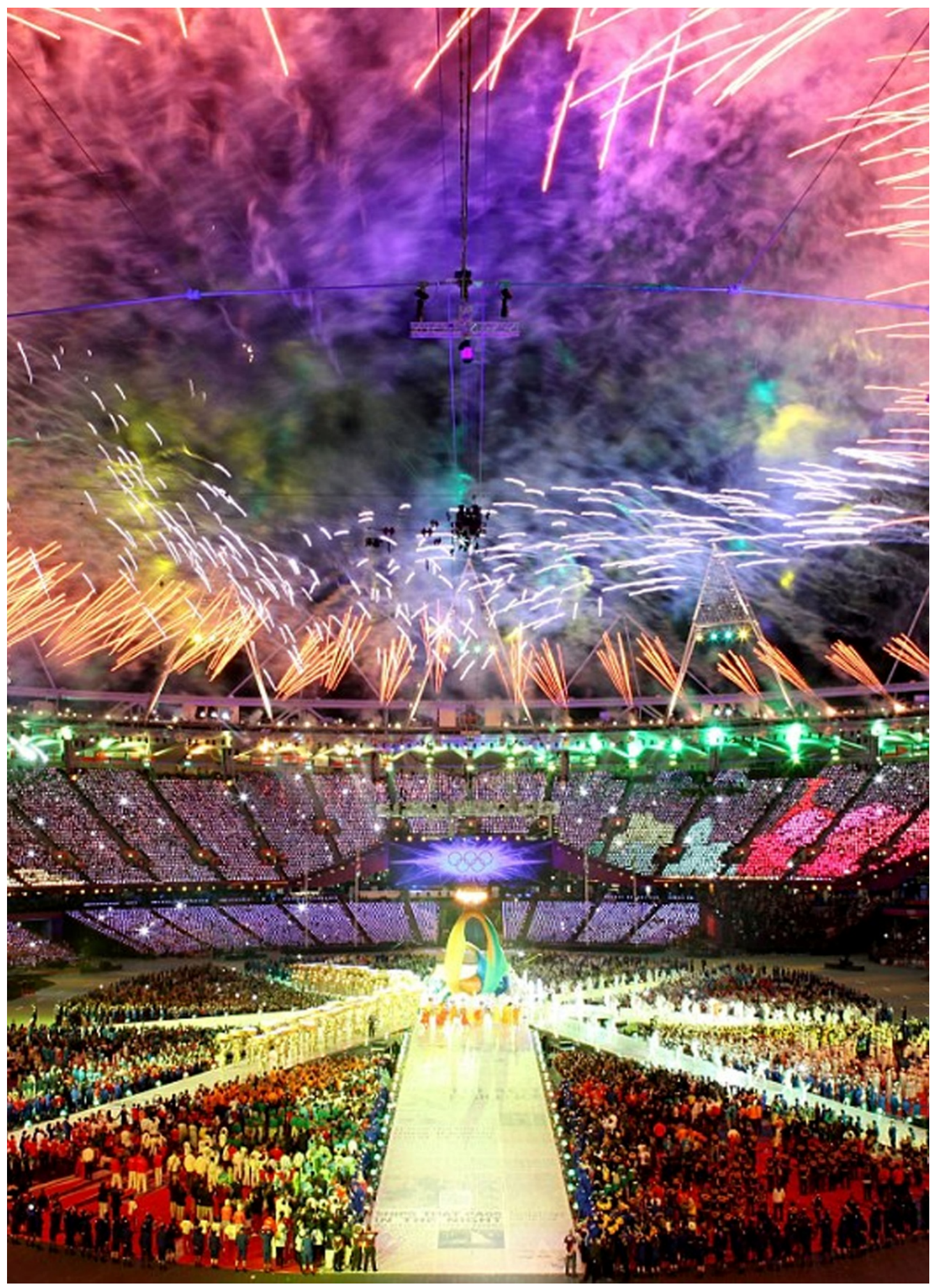




\section{Preface to COVID-19}

Fig. 3.

London

Olympic Opening Ceremony.

At the end of 2019 the emergence of a new, viral, zoonotic pathogen resulted in the outbreak of the Coronavirus disease. ${ }^{1}$ In March 2020 the World Health Organization declared COVID-19 a pandemic due to the rise number of international cases.

Originating in Wuhan, China, the virus spread to all regions within the country, then to Japan and further abroad. ${ }^{2}$ As of writing, COVID is now in most countries. It is a global concern and continues to cause disruption to human health and the global economy. ${ }^{3}$

COVID-19 has resulted in the cancellation or postponement of mass gatherings including sport related events such as the Tokyo 2020 (now scheduled for 2021) Summer Olympic Games. On March $24^{\text {th }}, 2020$ the International Olympic Committee made a statement to postpone the games, however they will retain the title. Therefore, in this thesis the Olympics will be referred to by their official year of 2020, even though it will be held in $2021 .^{4}$

\footnotetext{
${ }^{1}$ Gallego, Viviana, Hiroshi Nishiura, Ranjit Sah, and Alfonso J. Rodriguez-Morales, "The COVID-19 outbreak and implications for the Tokyo 2020 Summer Olympic Games," Trav Med Infect Dis 101604. (2020).

2 Ibid.

${ }^{3}$ Tokyo 2020, https://tokyo2020.org/en/ (accessed March 31, 2020). ${ }^{4}$ lbid.
} 
While this welcome decision is important in maintaining the health and wellness of the athletes and the public, the decision to postpone the games places additional financial pressure and hardship on Tokyo and the people of Japan - an event intended to symbolize the restoration of Japan after the Earthquake and nuclear disaster of 2011.

COVID-19 reinforces the critique of the financial waste of the games. The current cost of the games is predicted at 26 billion dollars. ${ }^{5}$ The financial strain will increase because of adjustments to preparation and responsiveness in reconfiguring the games' marketing, general affairs, energy, and new lease and maintenance fees to maintain the Olympic Venues and infrastructure for use in 2021. Like most Olympics, Tokyo's promise came with the assumption of strong spending related to game's tourism. ${ }^{6}$ With the pandemic however, Tokyo will suffer as a result of the global cancelation of commercial flights, the closure of current international borders, mass restrictions on travel mandated selfisolation and the slow return of economic strength after the end of COVID-19.

Olympic venues cost a fortune to maintain. Sydney's stadium costs 30 million a year in maintenance costs, and Beijing's Bird's Nest costs 10 million annually. ${ }^{7}$ These costs only mark one Olympic stadium and therefore do not include the costs for all the other venues, housing and many additional public projects. Most Olympic projects aim to sell the athlete accommodations in the Olympic village post games and lease other Olympic venues to defray costs, however due to pandemic, the cost of hosting the Tokyo 2020 Olympics will remain a burden for an additional year, with isolation providing no remedy for use or temporary occupation.

${ }^{5}$ Ibid.

${ }^{6}$ David Williams, "Tokyo 2020: a legacy or lethargy for tourism?," Josai International University, Faculty of Tourism Bulletin 25, no. 6. (2017): 51-66.

7 Simon Darcy, Tracy Taylor, "Managing olympic venues," In Managing the Olympics. (2013). 
Tokyo 2020 

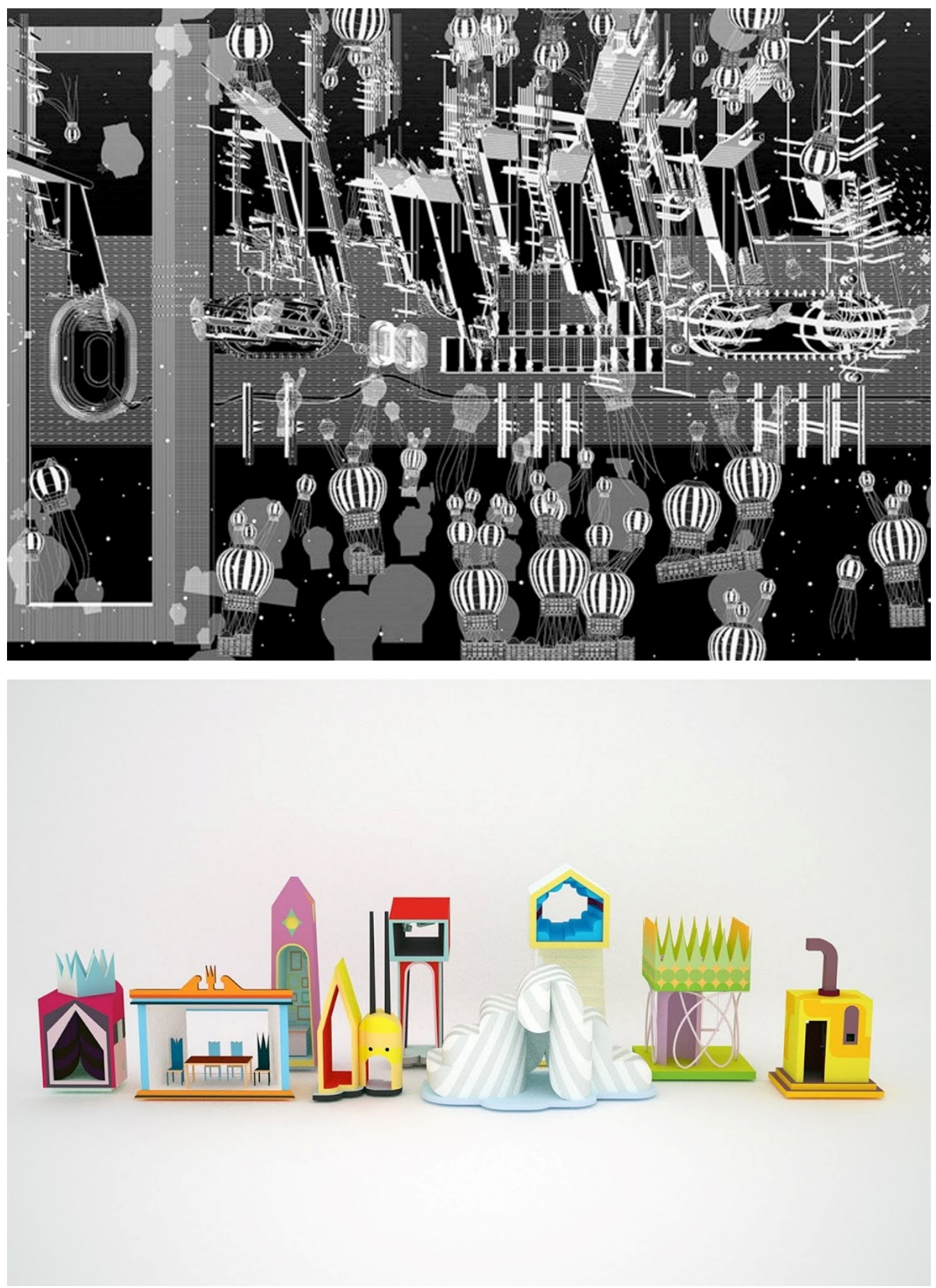


\section{Preface to Narrative}

Fig. 4. Narrative architecture is a research-by-design methodology that uses hybridized

Inhabitable

Infrastructure.

fictional drawings and models to articulate a narrative arc for an architectural project. It is used to speculate and reimagine architecture through unconventional designs and allows architects to explore new concepts and/or ideas. These ideas sponsor conversations about architecture in relation to contemporary issues which, in turn, evoke a critical rethinking of conventional methods.

I was introduced to narrative architecture as a design method when I pursued the Pre-

Fig. 5. Citizens of No Place: An Architectural Graphic Novel.

Master of Architecture program at the Bartlett School of Architecture, University College London in 2019. That pedagogy was characterized and supported through critical research and the extensive production of visual work. My experience at the Bartlett has strongly influenced how this thesis is approached. Supported by research and critical thinking, the project reiterates the Bartlett's overarching pedagogy as my thesis aims to imagine the economic and social cost of the Tokyo Summer Olympic games through a series of highly imaginative, playful images.

Contemporary examples of narrative architecture include the work of architects such as CJ Lim. His drawings for Inhabitable Infrastructure, a book published in 2017, display a dystopic future for a London flooded by the River Thames. Lim's project speculates how architecture might react to the results of climate change through a post-apocalyptic 
future. ${ }^{8}$ Other examples include the work of Jimenez Lai and his proposal for the "Township of Domestic Parts: Made in Taiwan," completed in 2014. Lai explores housing units of family life in Taiwan by investigating the relationship of eating, sleeping and entertainment within the common home. He interrupts these aspects to create nine small houses - depicting in each a single function, playing with scale, model and furniture to describe the modern home. ${ }^{9}$ These examples of playful interpretation and speculation have influenced the approach as aspirations of this thesis.

Narrative architecture can be used as a method for both built and unbuilt projects. In built work, it can help convey the building program or function, site context, historical significance and the client's interest through materiality, structure, form and detail in support of the buildings main message. In unbuilt work, it can be used to create idealistic utopian depictions of architecture. ${ }^{10}$

While the arc of narrative architecture as a method is varied, it typically begins by selecting a specific site and documenting it through personal experience and site analysis which includes a series of sketches, data, models, collages, film, drawings, or hybridizations of these varied techniques of drawing and model-making. Through the site analysis, a program is selected and designed to portray an idea. Next, the author mixes real and fictional elements from the site to construct a place that aims at exploring the possibilities within the unbuilt environment. It is often used to question current architectural issues, to reimagine conventional notions of space or drawing, or to speculate on 'what if' scenarios.

\footnotetext{
${ }^{8}$ CJ Lim, Inhabitable Infrastructures (New York: Routledge, 2017).

9 Jimenez Lai, Citizens of No Place: An Architectural Graphic Novel (New York: Princeton Architectural Press, 2012).

10 John Walker, "Visionary Architecture," Glossary of Art, Architecture \& Design since 1945.
} 
Narrative architecture is well known for its radical, unconventional and experimental designs. It is commonly used to portray fantasy-like worlds, however remaining critically adjacent to reality in order to help evoke possible architectural spaces. Its proponents deploy a variety of mediums that include, digital, and non-digital platforms such as collages, drawings, models and/or hybrids of both. This visual work makes it possible for an individual to share or highlight their views or stances on issues and to explore unconventional ideas in architecture. The theoretical framework opens a door for critical thinking and an individual to engage and be drawn into what the author chooses to depict. $^{11}$

${ }^{11}$ lbid. 


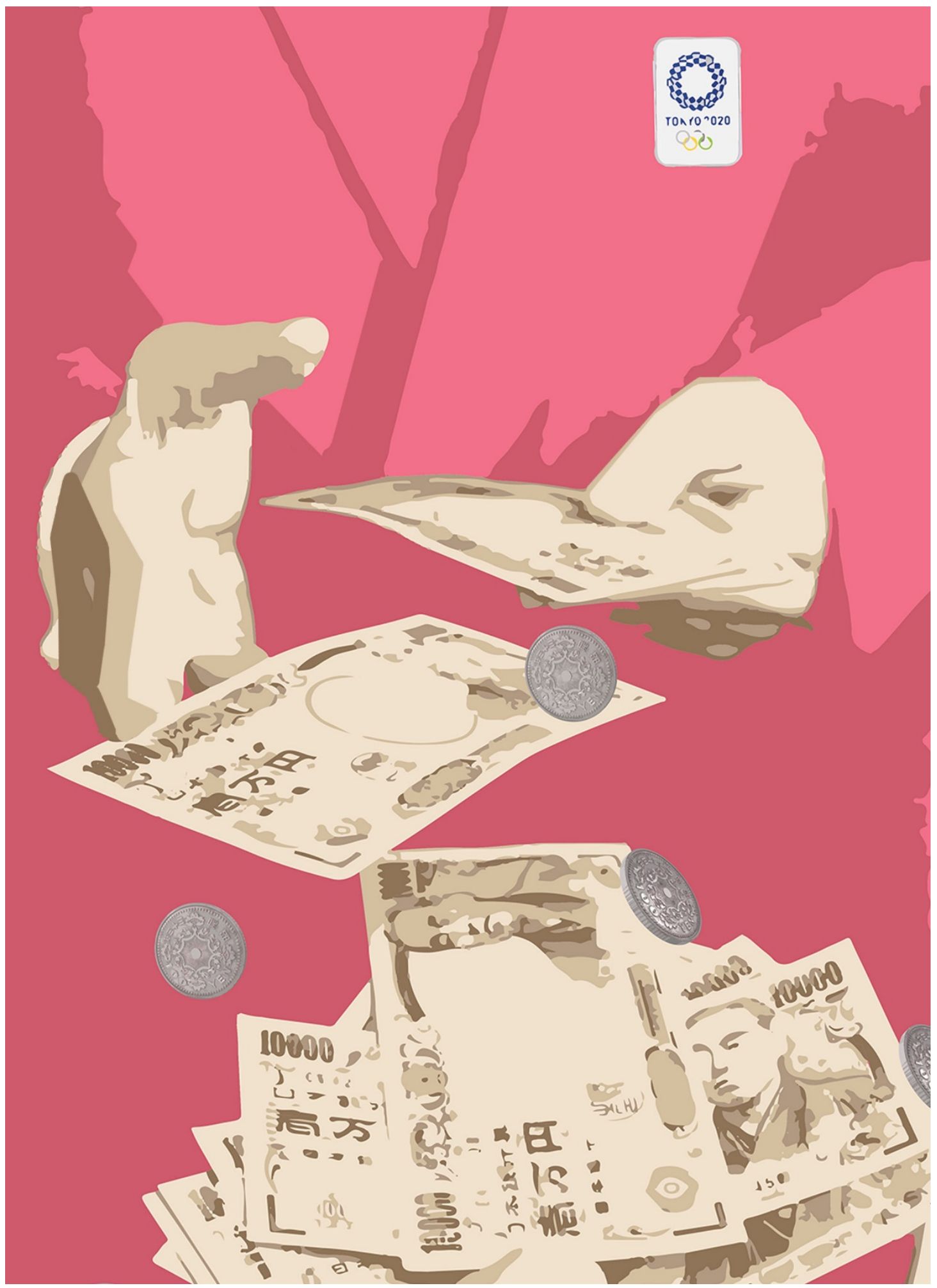




\section{Introduction}

Fig. 6. Olympics for Profit.

This dissertation is a speculative critique of the financial waste generated by the 2020 Tokyo Olympics. Using narrative architecture as a research-by-design methodology it questions how the Government of Tokyo will spend the funds related to hosting the Olympic games and how hosting such financially intensive events can leave the host city billions of dollars in debt. Cities have been leveraging the idea of the Olympics as a strategy to improve their image in order to gain global media attention, investments, and sponsorships with the 'promise of a long-term imagery enhancement for tourism and community pride'. ${ }^{12}$ In reality, however, hosting such events has ancillary economic, social and environment hardships.

The drawings intend to show a sequence of spaces to reveal the relationships between building, event, and financing. At the centre of the project is a hypothetical Bank for the 5.6-billion-dollar contingency fund allocated to the Olympics. Located in Shinjuku, directly underneath the central train station, the Bank links the busiest transit node in the world to the offices of multi-national corporations and Tokyo's Municipal Office Building. In this Bank money is transferred, shifted, "washed," and moved: the

\footnotetext{
${ }^{12}$ Guillaume Bodet, James Kenyon, "Exploring the domestic relationship between mega-events and destination image: The image impact of hosting the 2012 Olympic Games for the city of London," Sports Management Review. (2018): 232-249.
} 
To Discover A New Tomorrow

movement of money mirroring the movement of people and goods on the streets above.

The design thesis is expressed through a series of collages and drawings to illustrate site analysis, character studies and architectural interventions. These images are intended to hypothetically expose and explore the relationships noted above, as they relate to the Olympics and its funding. 
Fig. 7.

Olympic

Site

Proposal.

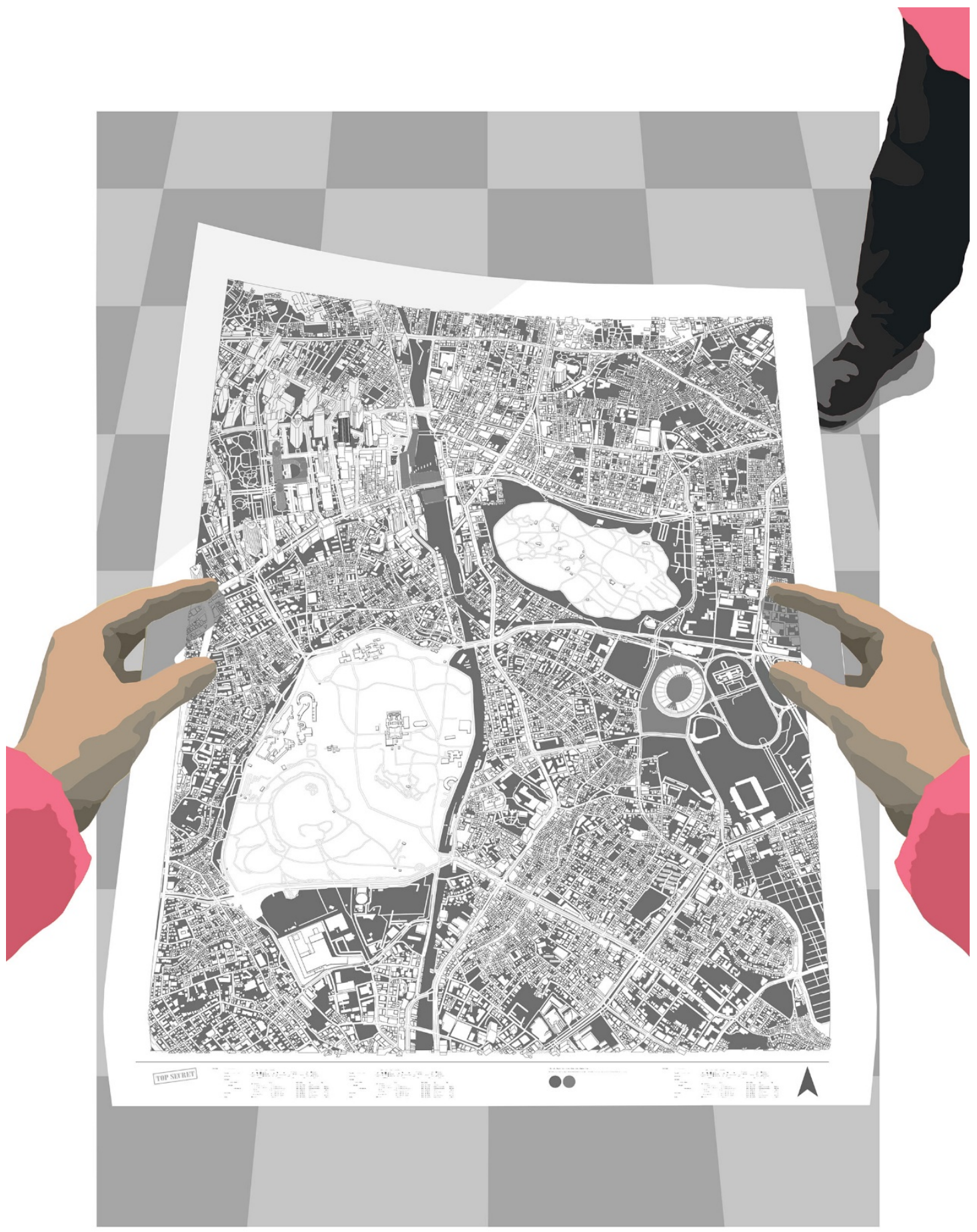




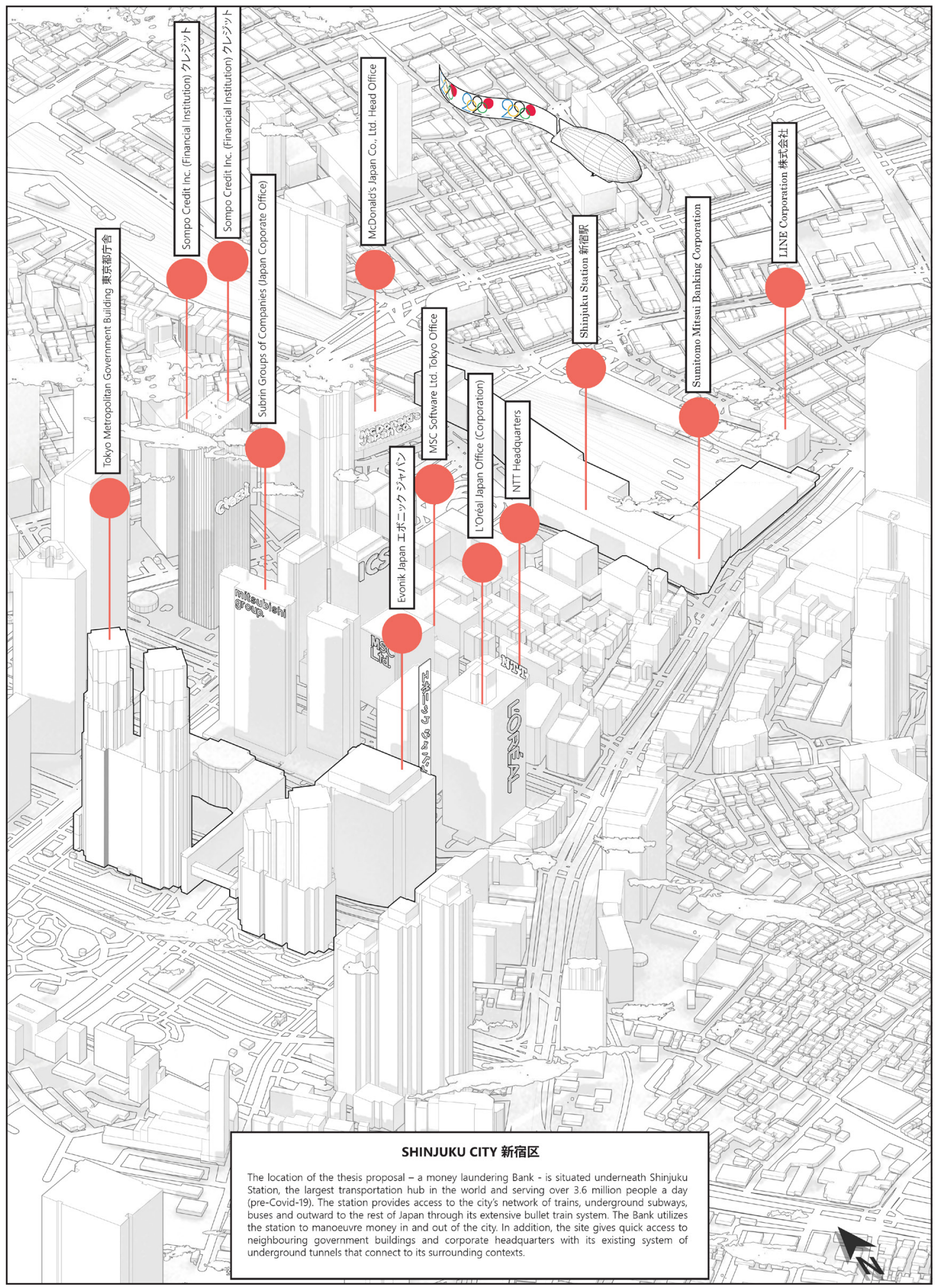




\section{Site}

Fig. 8. Site The site is located in the fourth ward of Tokyo: Shinjuku City. Located approximately Location. $8 \mathrm{~km}$ from the city centre, Shinjuku is in the northwest end of Tokyo and borders Shibuya City and Chiyoda City. Shinjuku is Tokyo's major commercial and administrative district. It contains the Tokyo Metropolitan Government Building - the administrative centre for the government of Tokyo - as well as numerous corporate headquarters, and massive shopping centres. Corporate headquarters include, but are not limited to, the regional telephone operator NTT East, Olympus Corporation, Classi Corporation, McDonalds Japan, Mitsubishi group, Evonik Japan, MSC Ltd., L'Oreal, and Subaru.

The ward contains three Olympic venues for the Tokyo 2020 Olympic Summer Games, including the new Olympic Stadium designed by Kengo Kuma. Shinjuku contained the existing 1964 Olympic Stadium which was demolished to make way for the Kuma's project. This contradicts the Government of Japan's statement in the Olympic Bid for sustainable reuse of venues, reinforcing the concerns of the thesis regarding economic waste.

The location of the thesis proposal - a money laundering Bank - is situated underneath Shinjuku Station, the largest transportation hub in the world and serving over 3.6 million people a day (pre-COVID-19). The station provides access to the city's network of trains, underground subways, buses and outward to the rest of Japan through its 
To Discover A New Tomorrow

extensive bullet train system. The Bank utilizes the station to manoeuvre money in and out of the city. In addition, the site gives quick access to neighbouring government buildings and corporate headquarters with its existing system of underground tunnels that connect to its surrounding contexts. 
Fig. 9. Site Location in Plan.

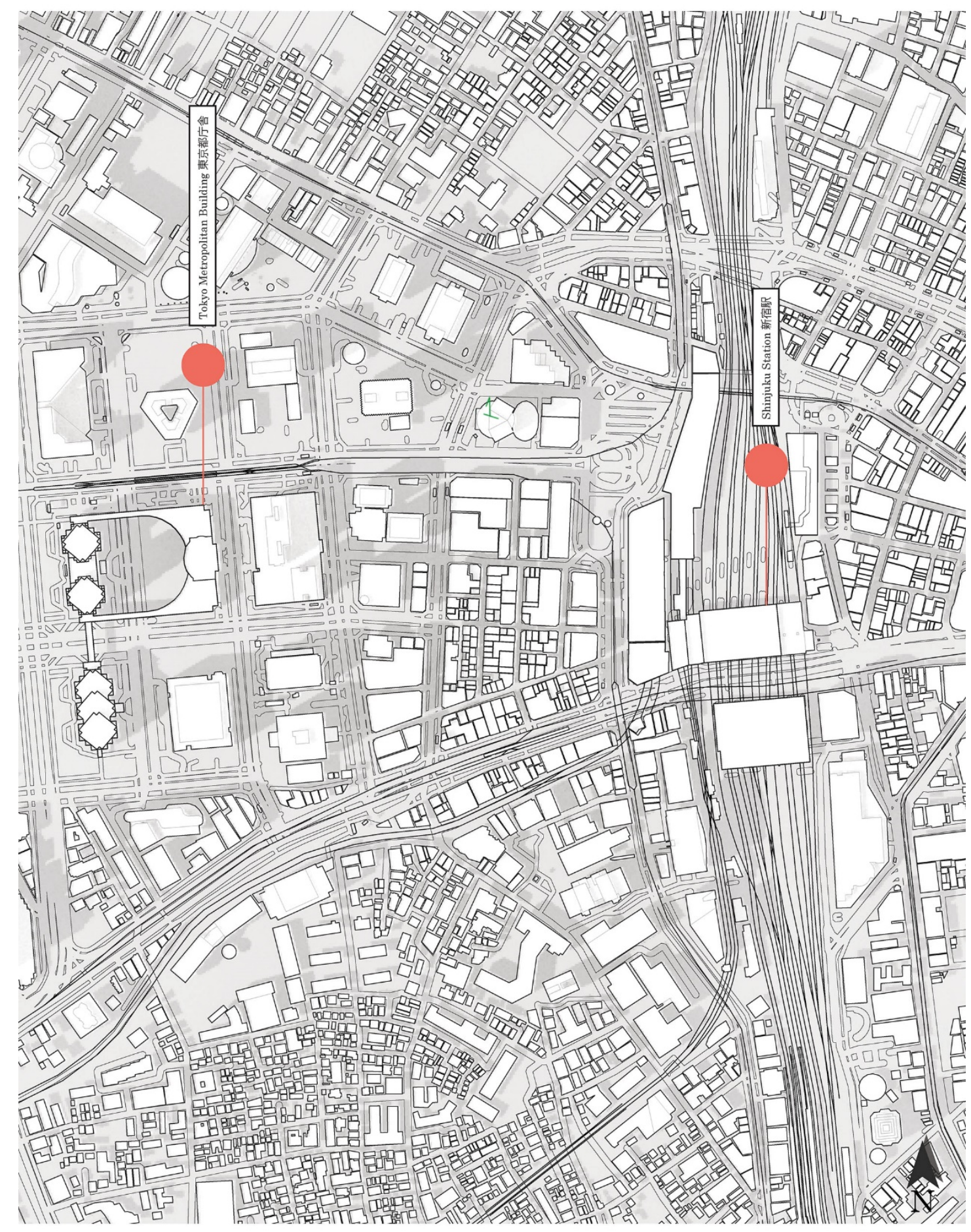


Fig. 10.

Construction Photo.

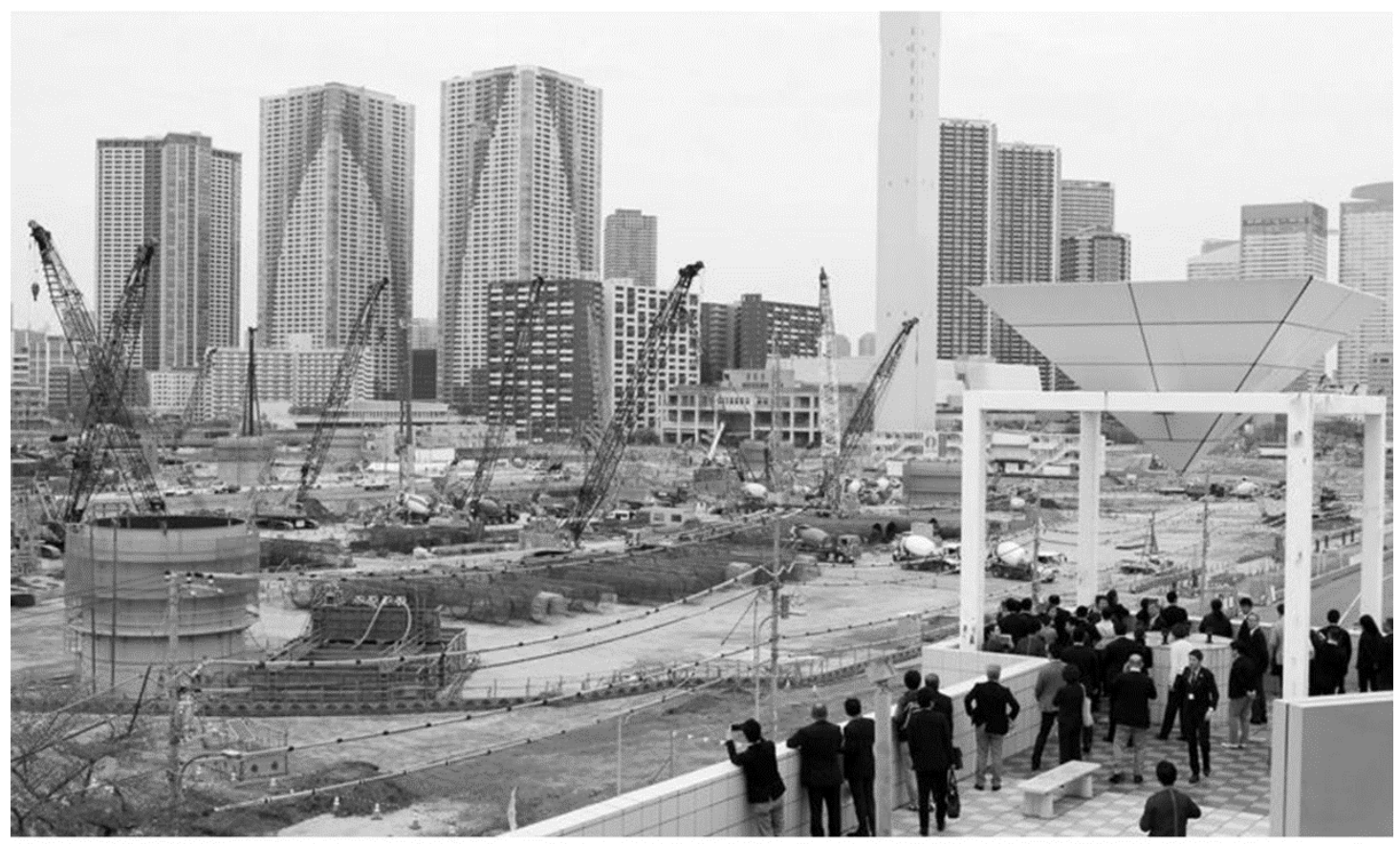

Fig. 11.

Construction Photo 2.

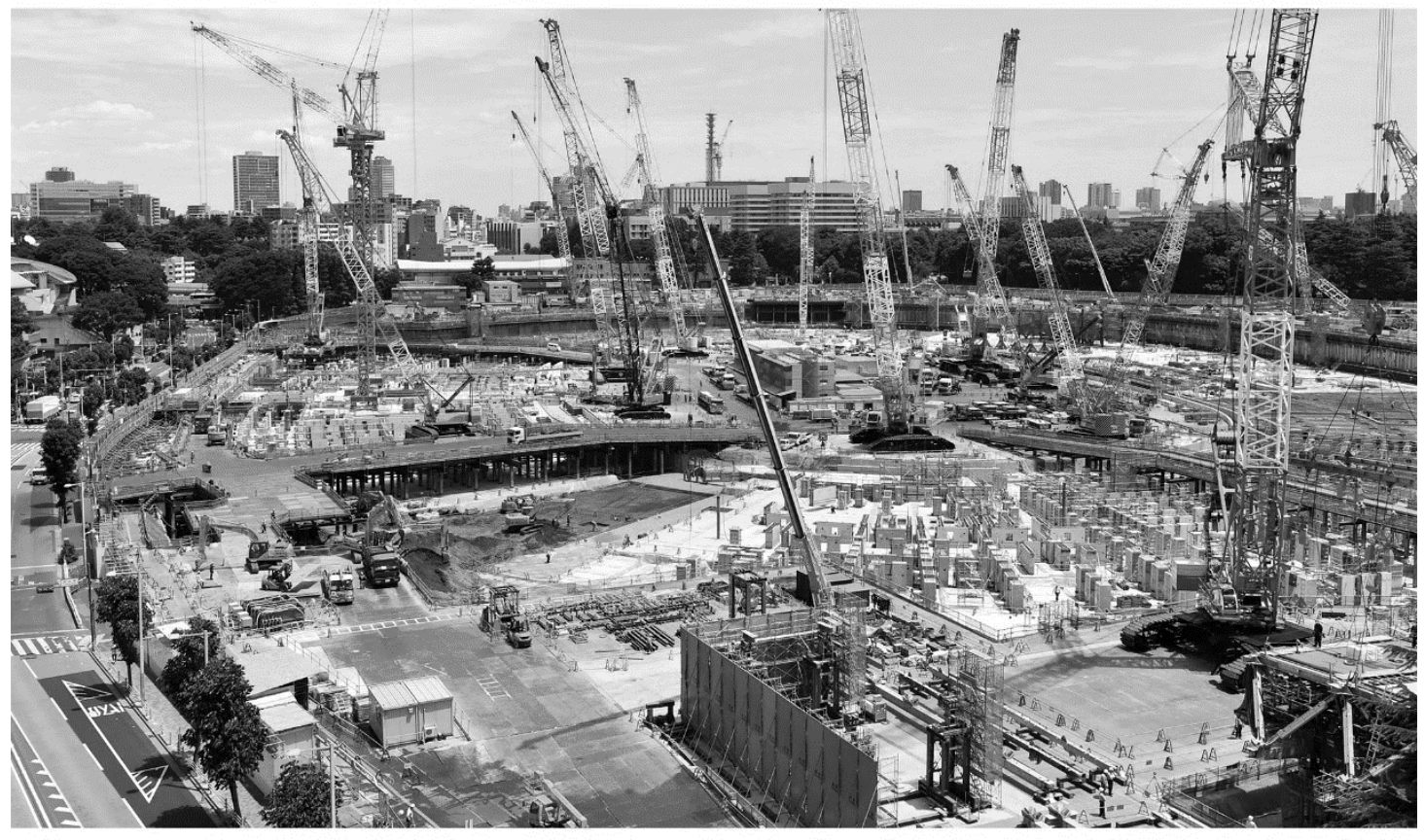


Tokyo 2020

Fig. 12.

Con-

struction

of New

Olympic

Stadium.

Fig. 13.

Con-

struction

of New

Olympic

Stadium 2.

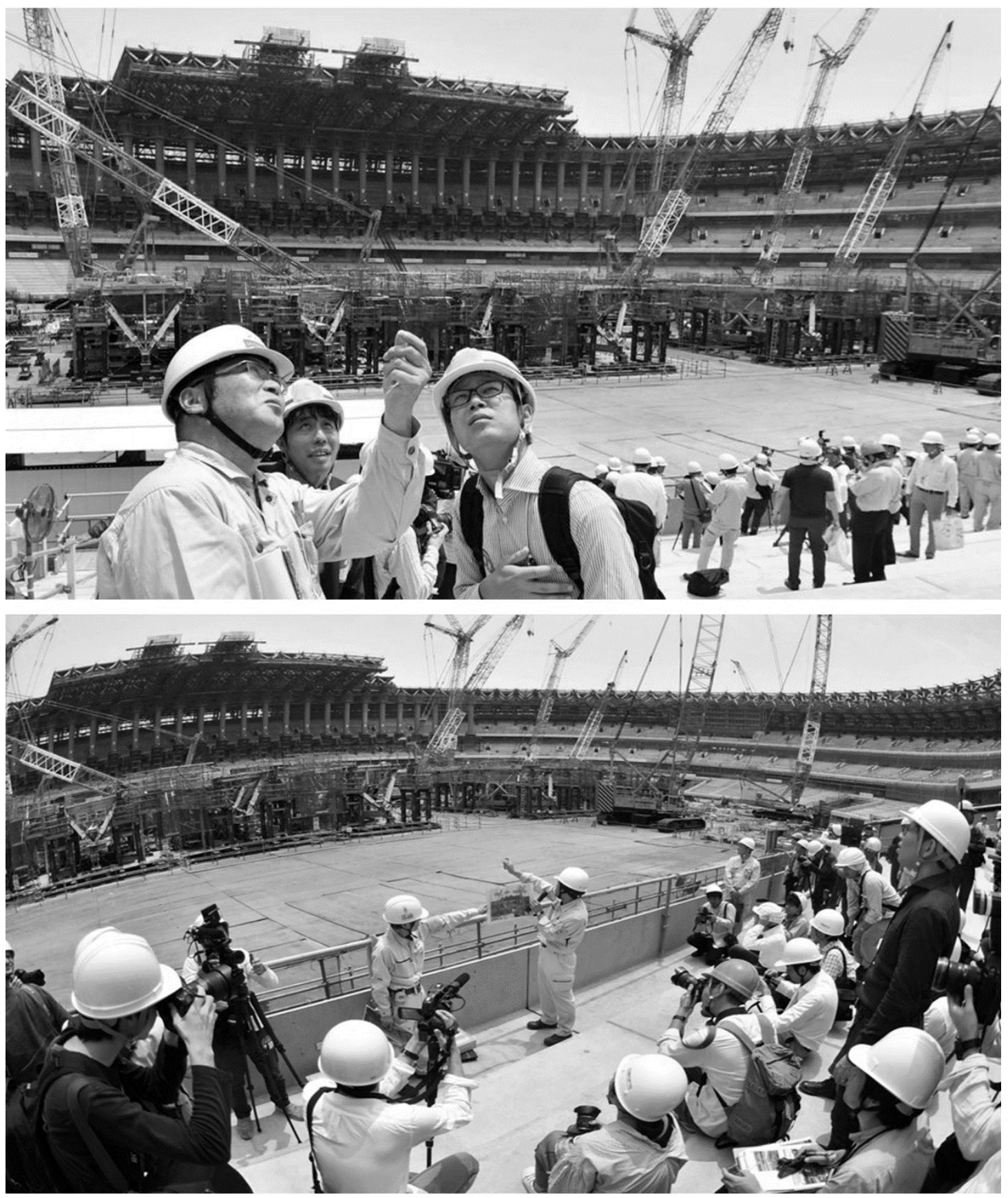


Fig. 14. X-Ray Illustrations of Tokyo Train Stations.

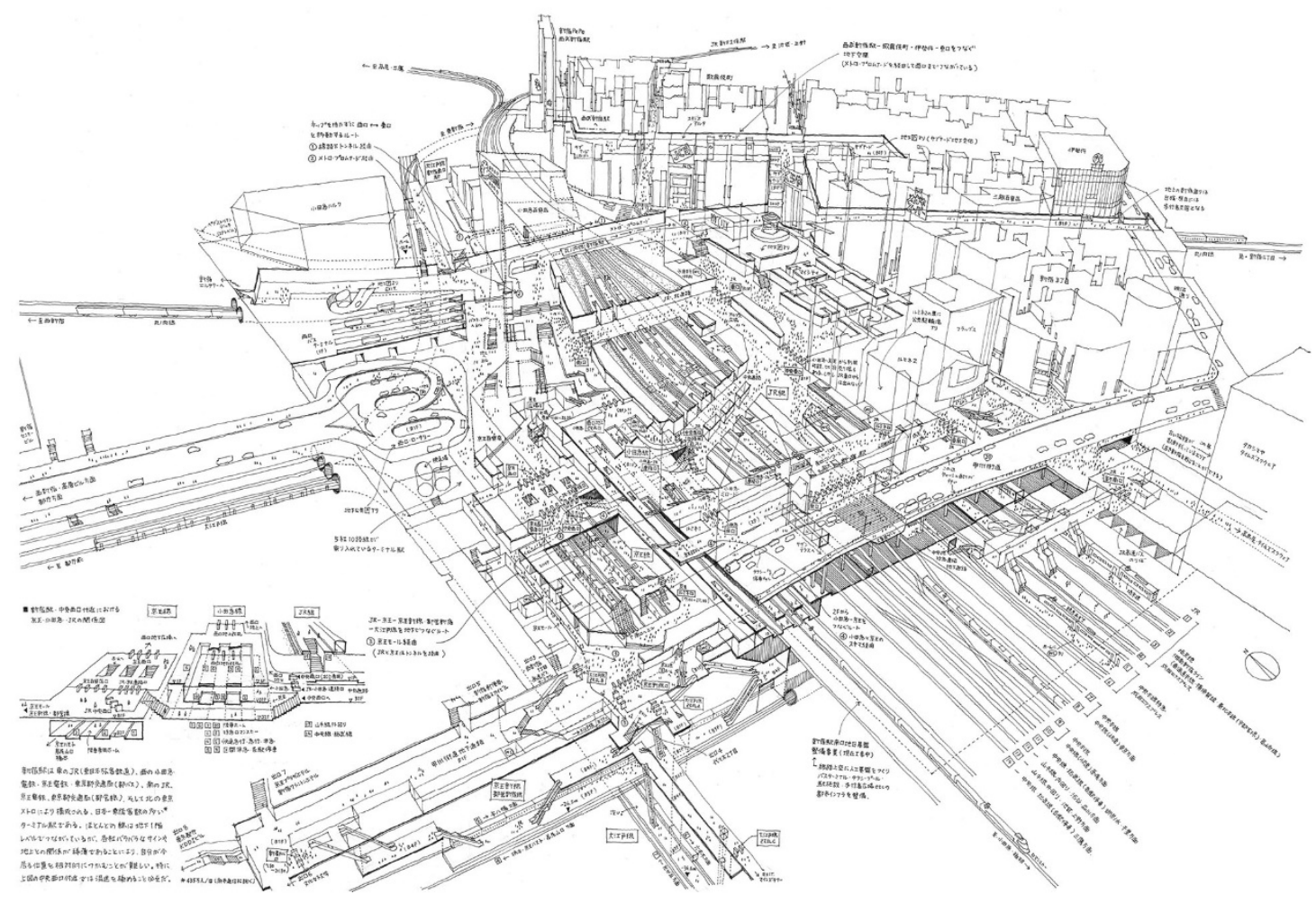


Tokyo 2020 


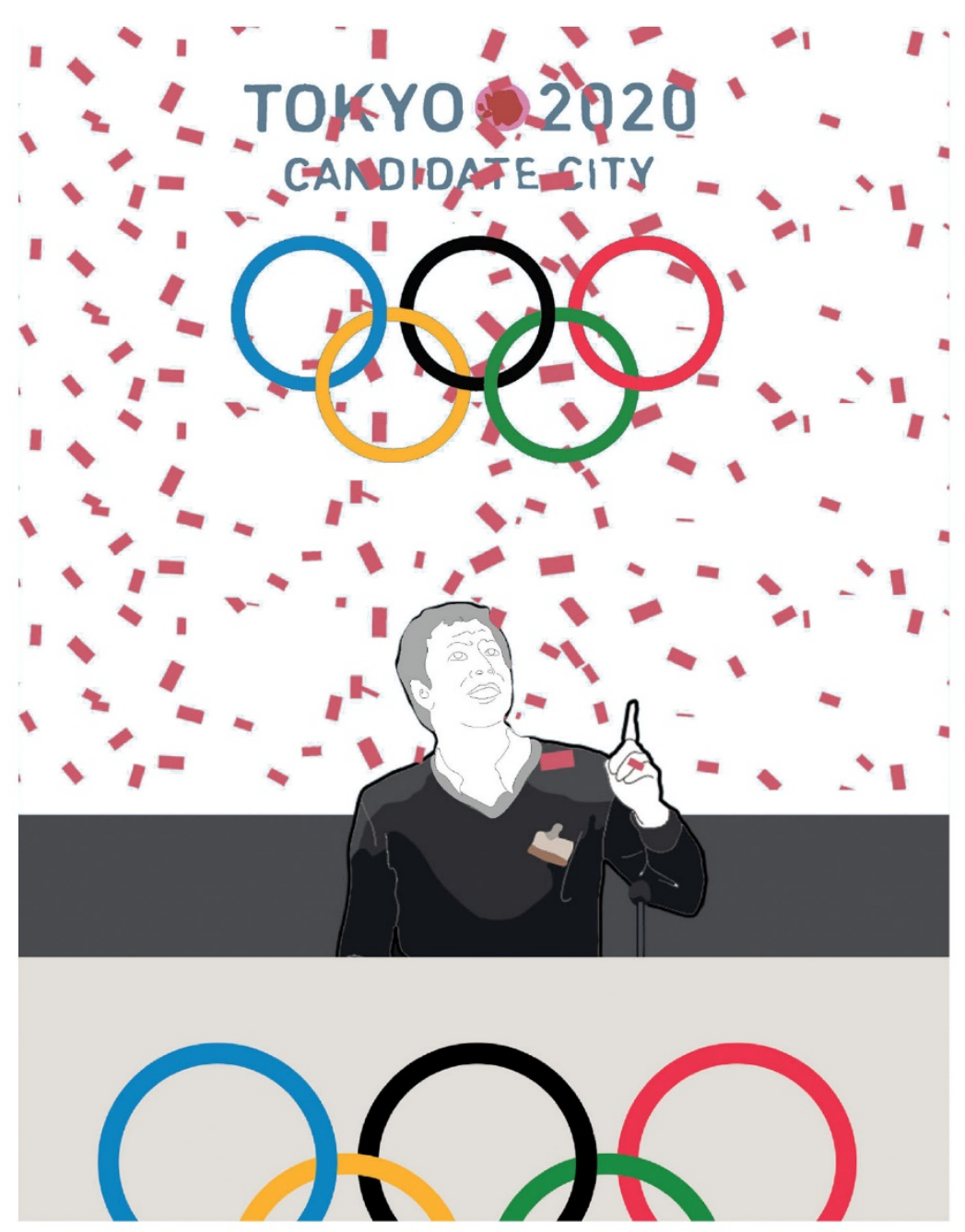


Tokyo 2020

\section{Olympic Games}

Fig. 15. Inspired by the Panhellenic Games in ancient Greece, the Olympic Games is a modern

Olympic

Win.

international sports competition held once every two years. They alternate between Summer and Winter sports and consecutive Summer (or Winter) games are four years apart. Cities bid to host the event, and the resultant competition is open to more than 200 nations and takes place in a new country in every Olympic Games.

In modern times, host cities use the Olympic Games to improve their image and reputation, to gain sponsors, investors and tourism. Cities attempt to demonstrate the host nation or city's political, economic, and cultural prestige to the world through extensive media coverage. The Games use the construction of brand-new infrastructure, new event-related sport venues and iconic architecture to recreate cultural heritage narratives in aid of improving or reinventing the host nations image. ${ }^{13}$ To fund this global event, however, the games in recent times have had to gravitate towards a more corporate structure for consumers. ${ }^{14}$

Hosting the two-week games often leads a host city (and their country) into billions of dollars of debt. Robert Barney, head of the International Centre for Olympic Studies,

\footnotetext{
${ }^{13}$ Mike Featherstone, Tomoko Tamari, "Olympic Games in Japan and East Asia: Images and Legacies: An Introduction." International Journal of Japanese Sociology, no. 1 (2019): 4.

${ }_{14}$ John Davis, The Olympic Games Effect: How Sports Marketing Builds Strong Brands (Wiley \& Songs, 2008).
} 
claimed that no city has ever made a substantial profit from hosting the Olympic Games in its 117 years modern-day history. ${ }^{15}$ Politicians, however, argue that the games have become significant investment and effective marketing strategy for the host city. ${ }^{16}$ While data confirms the influx of tourism and successful improvements to transportation, ${ }^{17}$ the games typically encounter a large number of challenging economic, social and environmental issues: including water pollution, smog, and unsustainable infrastructure which typically leads to low-use venues with high energy consumption. An additional reason for hosting is that cities commonly bid to improve sports participation and promise a better image of the city to the outside world. There is little to no evidence, however, that suggests there is any success or impact in activating exercise or producing long-term imagery enhancements of the city. An example of those was seen in the submission and subsequent promotion of the London 2012 Olympics where the Olympic Committee and UK Government used media outlets to advertise the resulting regeneration projects of East London to host the Olympic facilities as a positive legacy for the people. By using marketing strategies to positively enhance the idea of the new construction associated with hosting the Olympics, the Government and Committee distributed articles, symbols and images throughout the city and online. The result of the project was the construction of low-use Olympic venues which gentrified the area; thus, failing to meet their campaign's promises of a long-term community enhancements and individual sports participation. ${ }^{18}$

\footnotetext{
${ }^{15}$ Richard Morrow, "Tokyo's Costly Olympic Win." Asia. (2013). 16 lbid.

${ }^{17}$ Guillaume Bodet, James Kenyon, "Exploring the domestic relationship between mega-events and destination image: The image impact of hosting the 2012 Olympic Games for the city of London," Sports Management Review, (2018): 232-249.

${ }^{18}$ Andy Thronley, "The 2012 London Olympics. What is Legacy?," Journal of Policy Research in Tourism, Leisure and Events. (2012): 297.
} 
This is the controversial underbelly of hosting the Olympics, where governments use a large concentration of resources towards a two-week mega-sport event rather than other potential significant, but less visible projects for the host city. In addition to the resources used, this urban development results in negative consequences such as rapid gentrification and social exclusions to the existing community. ${ }^{19}$

This thesis aims to acknowledge these questions without proposing an answer to mitigate the social issues - which is another multi-scalar project in its own right. The speculative development of a Bank, and its illicit activities underscores the issues associated with hosting the games. This thesis focuses solely on the financial relationship of the varied government funding sources, corporate sponsorship and the individuals that stand to financially benefit from such a massive transaction.

${ }^{19}$ Mike Featherstone, Tomoko Tamari, "Olympic Games in Japan and East Asia: Images and Legacies: An Introduction," International Journal of Japanese Sociology, no. 1. (2019): 4. 
Fig. 16.

Financial

Data.

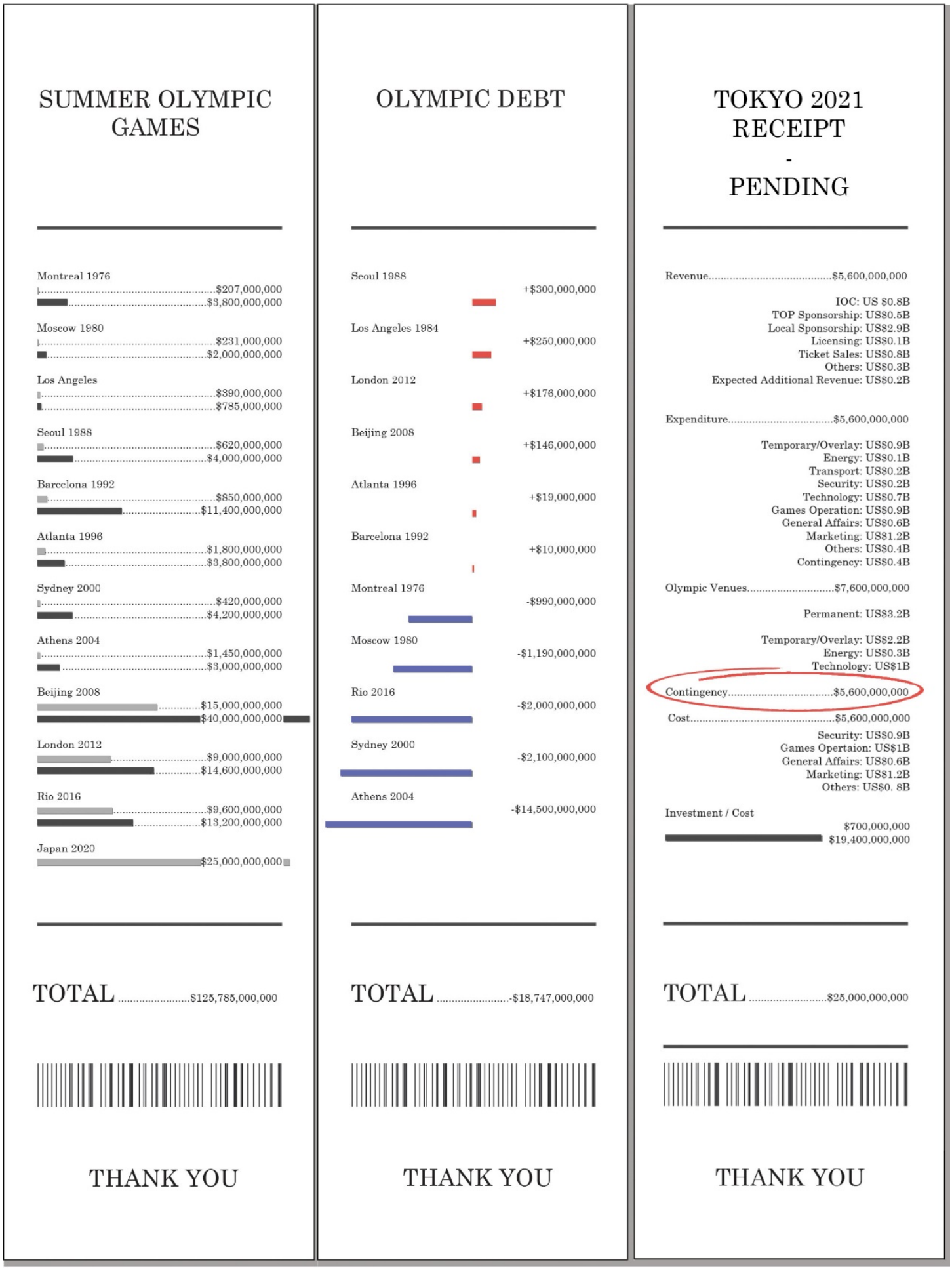


Tokyo 2020 


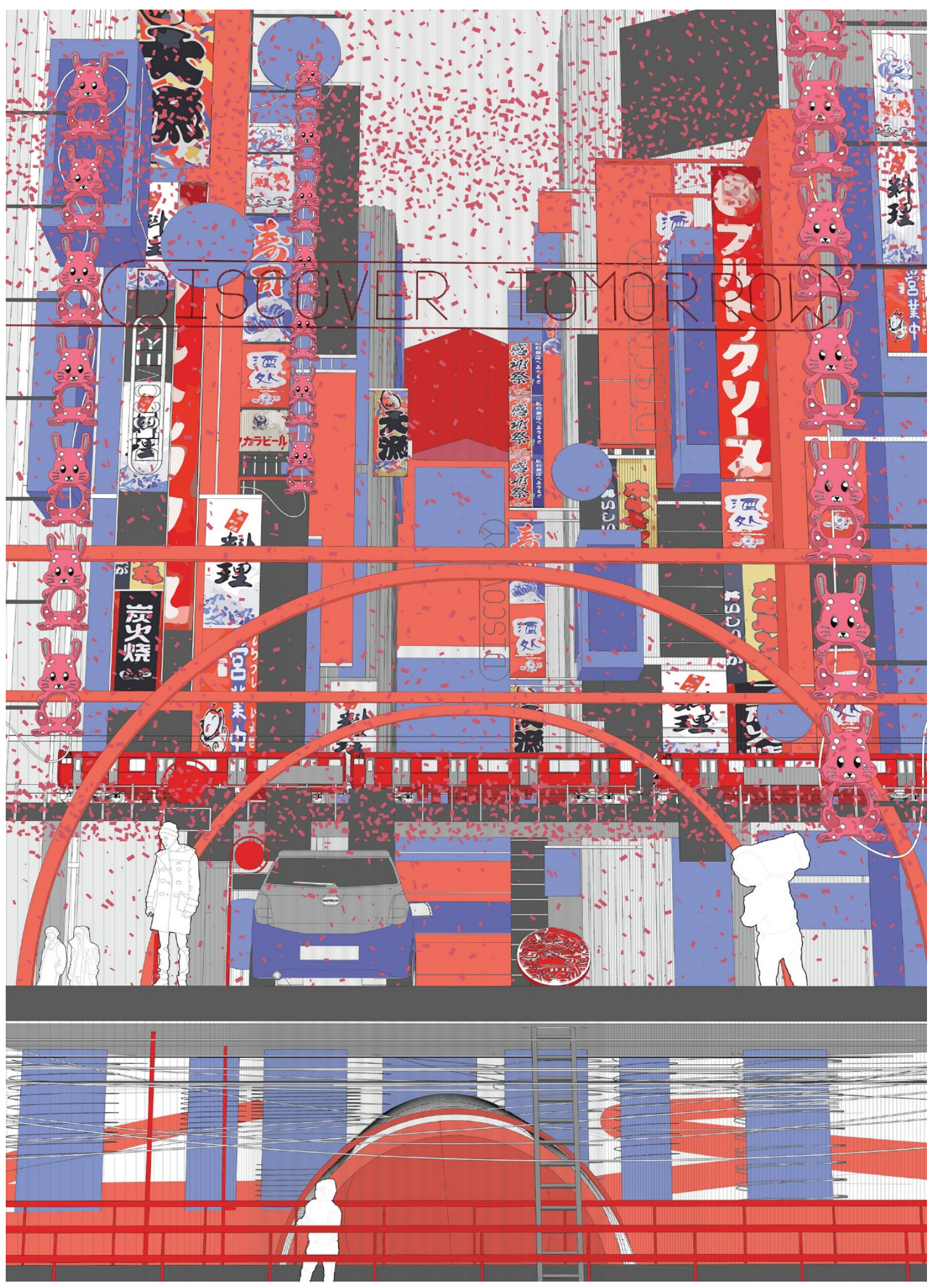


Tokyo 2020

\section{Tokyo 2020}

Fig. 17. "In the past years, the Tokyo Metropolitan Government has undertaken efforts to clean Tokyo's Regeneration Plan - Part 1. up the area's seedy image for the upcoming Olympics. The district now offers a mix of reputable and questionable establishments sharing walls, but the perception still remains". ${ }^{20}$

On September 7th, 2013, Tokyo won the bid to host the 2020 (now 2021) Summer Olympic and Paralympic Games through the promise of developing competition venues with state-of-the-art technologies, unifying diversity and passing on a legacy to "Discovery a New Tomorrow". ${ }^{21}$ Tokyo's Government made an effort to clean up the area's 'seedy image'22 for the mega-sport game event in order to create a reputable image to the external world. The Olympic promises included improving the urban environment, revitalising areas, expanding green spaces and creating an interface between cities and waterfront. ${ }^{23}$

${ }^{20}$ Mareike Dornhege, "Shinjuku Ward Guide: Tokyo's Beating Neon Heart." REthink Tokyo - Real Estate Information for Buyers and Investors, (2019). https://www.rethinktokyo.com/shinjukuarea-guide. (accessed September 30, 2019).

21 "Tokyo 2020 Action \& Legacy Plan 2016," Legacy Summary, https://tokyo2020.org/en/games/legacy/items/legacy-summary_EN.pdf. (Accessed September 16, 2019).

22 Ibid.

${ }^{23} \mathrm{lbid}$. 
The Tokyo 2020 Organising Committee, Government of Japan, The Tokyo Metropolitan Government, Japanese Olympic and Paralympic Committee are collectively responsible for implementing proposed comprehensive action plans to deliver pre- and post-game legacies.

Regeneration plans included the removal of visible telephone poles and wires to create a 'cleaner' image of Tokyo as well as redeveloping the Meji Jingu district with the New Olympic Stadium and park to prepare for mass spectators within Shinjuku. This 'cleaner image' of Tokyo included the demolition of the previous 1964 Olympic Stadium to make way for the new Olympic Stadium.

Fig. $16 .{ }^{24}$ and Fig. $16 .{ }^{25}$ display two sectional perspectives showing the streets of Shinjuku. The first drawing displays the main street celebrating the upcoming Olympics above ground, with the power lines below grade. The drawing represents the front-ofhouse view of the major streets and its curated civic life versus the hidden back-ofhouse which shows elements of infrastructure that are required to run Tokyo. The second image is a side street that depicts the opposite street condition. It displays the electrical infrastructure above ground. The purpose of the drawings is to reflect on the complex relationship of Tokyo's public perception versus the infrastructure required to maintain that perception to the outside world. Here the image is a microcosm of the Olympic Games itself, as an event that is highlighted for two weeks, however, requiring years of preparation and attention and extensive hidden systems for its success.

\footnotetext{
${ }^{24}$ Angela Chiesa. "Tokyo's Regeneration Plan - Part 1", 2019.

${ }^{25}$ Angela Chiesa. "Tokyo's Regeneration Plan - Part 2", 2019.
} 


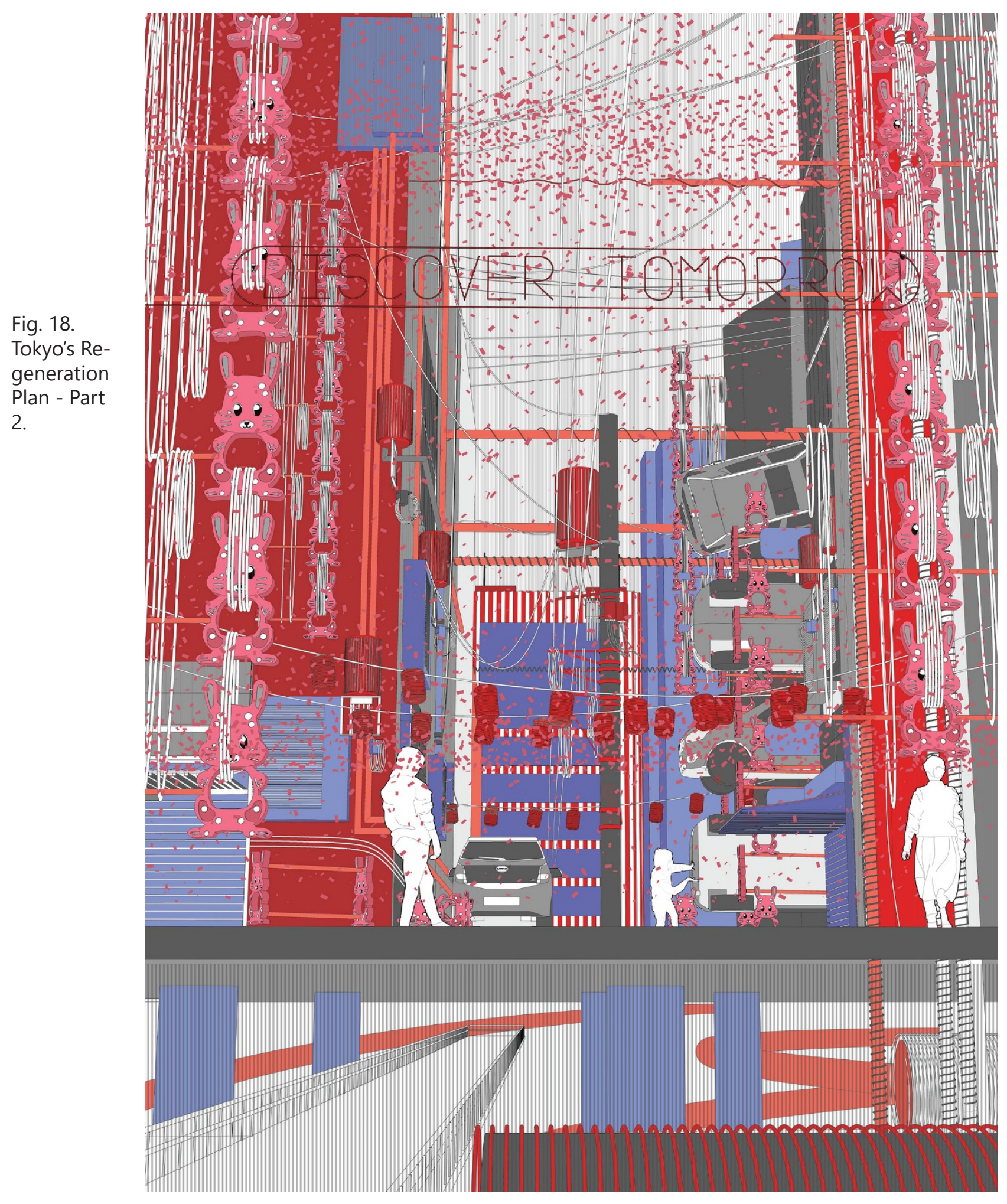




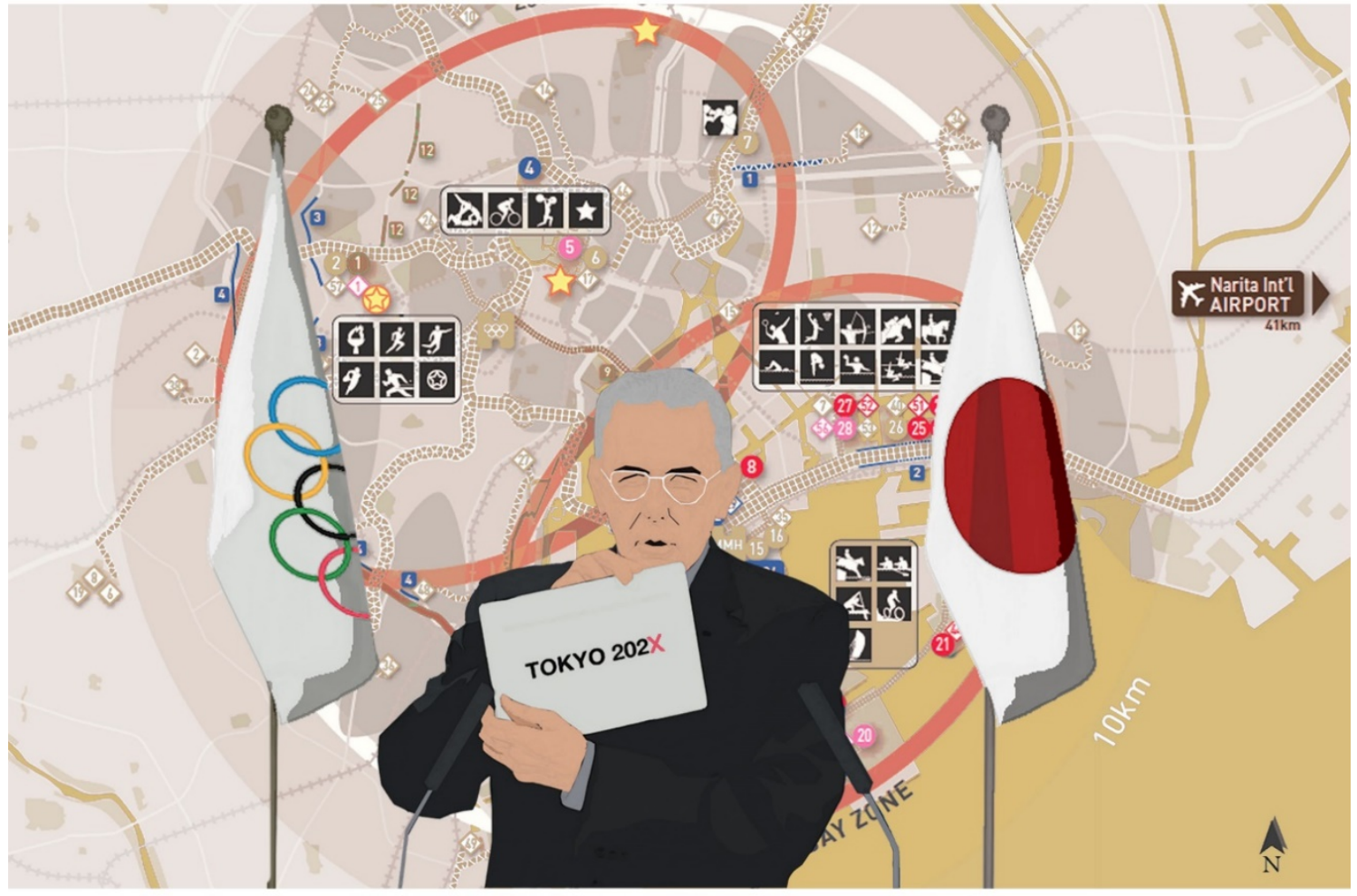


Tokyo 2020

\section{Project Narrative}

Fig. 19. This thesis uses a series of signs, slogans and propaganda to reiterate the central Narrative Introduction. message of the Games, but inverts these objects and uses them as a front used to market the games as a positive legacy while simultaneously hiding its negative underbelly. The front is used to describe the façade that the Government of Japan and the International Olympic Committee put on display to portray the positive aspects of Tokyo 2020 while hiding all the other, less positive aspects, from view. The thesis is structured into four moments to describe this narrative and the design of the project. As each moment is shown, it exposes the issues surrounding the Olympics and its funding.

To visually reinforce the economic theme of the work, the graphics and infographics use a series of repeated signs, slogans and propaganda, to promote the Summer Games as a way to critique the overt marketing the Government of Japan is using for the event as a front that promise a positive legacy for the city. In contrast, this thesis raises awareness to issues that include overbudget spending and deaths related to the construction of the New Olympic Stadium. This is done through the repeated use of construction pilons and overspending of the Bank's construction to reiterate the overall narrative. The design includes exaggerated floor to ceiling heights, long hallways consisting of ATMs and numerous large scaled vaults. 
The symbols used throughout the drawings include a plastic rabbit - the playful construction pylons used around the new Olympic Stadium, the slogan 'To Discover a New Tomorrow", and the cooling fans and umbrellas that have been passed around Tokyo for advertising. These are intended to be simple yet clear graphics to make the thesis visually cohesive and to draw the viewer in through the images.

The thesis depicts several particular characters and moments. The main characters include the head of the International Olympic Committee, Thomas Bach, and the Japanese Prime Minister, Shinzo Abe, as they are the current figures for the Tokyo 2020 Summer Olympic Games. The figures in the drawings are repeated characters from executive and corporate positions, drawn in business attire, carrying briefcases.

The four moments include (1) threshold drawing, (2) money collection, (3) money laundering, and (4) the vault within the Bank. The threshold drawing is the beginning of the narrative as the viewer is situated at the entrance of the project as it transitions from above to below grade.

The money collection image displays the flow of money transitioning from above grade to below grade in the tunnel-like Bank.

The money laundering drawing depicts the transaction of cash flow and the hidden processes within Shinjuku Station.

The vault drawing displays the process of construction of the Bank and the hidden financial resources. 
Fig. 20.

Characters.

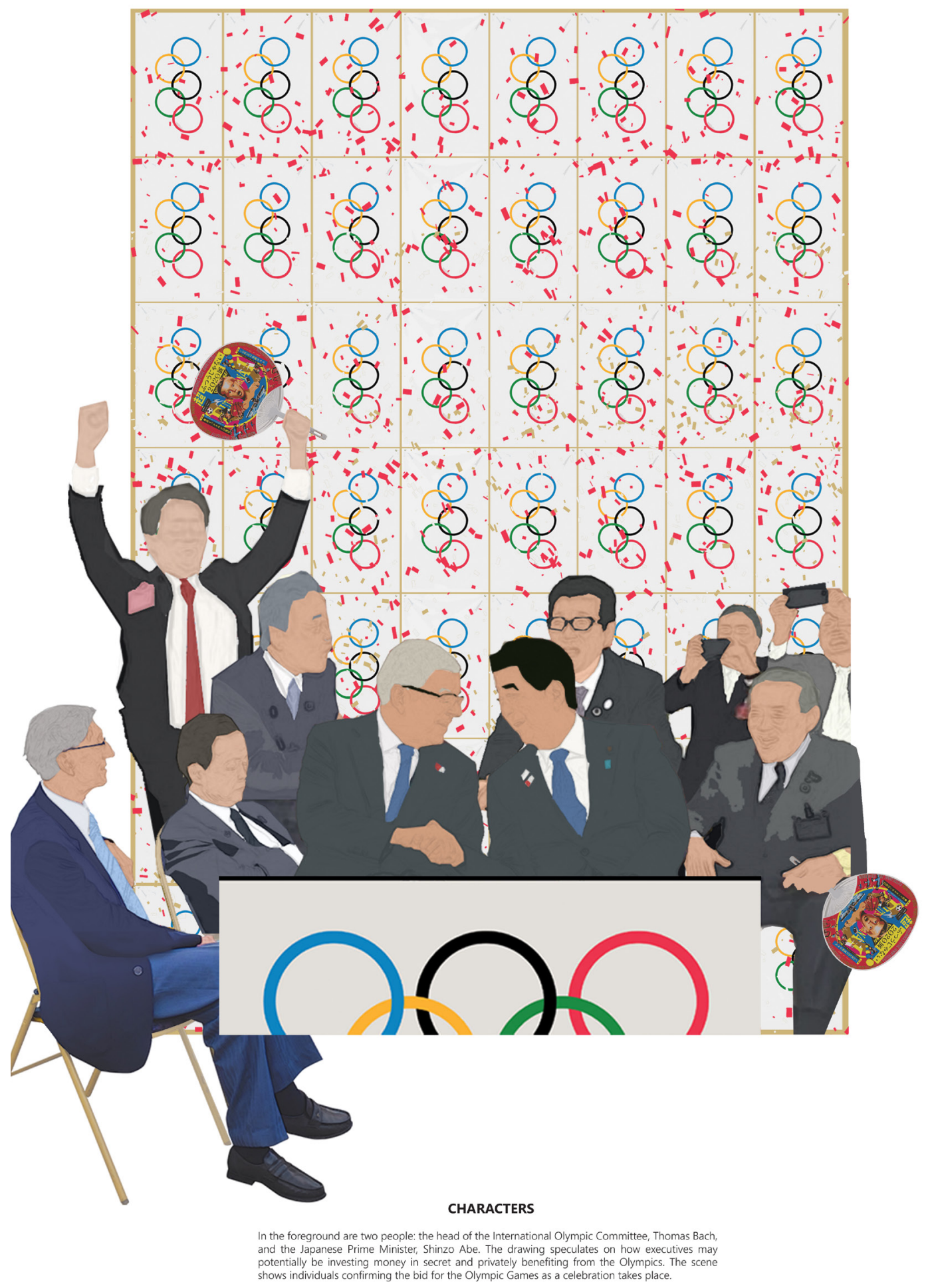




\section{Threshold}

The drawing is divided into a background, middle ground, and foreground. The drawing displays a perspectival streetscape of Shinjuku Station. In the foreground are two people: the head of the International Olympic Committee, Thomas Bach, and the Japanese Prime Minister, Shinzo Abe. The drawing speculates how executives may be investing money in secret to privately benefit from the Olympics. The scene shows individuals confirming the bid for the Olympic Games as well as plans for the Bank, as a celebration in Shinjuku takes place.

The image includes a series of store fronts in the middle ground which displays two fan shops. The fan shops are the entrances to the Bank - a commercial shop disguised as a literal and representational front for the upcoming games. This is the entrance for the characters in the foreground.

In the background, the rabbits are used as a symbol to critique the façade of the Tokyo Olympics as a promise of a long-term legacy for the city and its visual enhancement. This critique is rooted in the disconnect between the image and its hidden reality. As the New Olympic Stadium was being built, pylons in the form of cartoonish rabbits were used to block off parts of the construction. As the construction for the Olympic Stadium progressed several construction deaths occurred on site due to the overworking of the construction workers. The project therefore re-uses the existing 
pylons as both a commentary and symbol of the Olympics' harsh, and often, less visible realities.

The Olympic slogan, "To Discover a New Tomorrow", is shortened to 'Discover Tomorrow' and is used as a symbol to the entrance of the Bank. The slogan serves as a hypocritical commentary and a play on words. It is meant to describe the security the Bank provides to the financial investors, with the core purpose of securing future profits for the clients involved. Confetti falls throughout the streetscape in celebration of the games above ground. The slogan and celebration are meant to represent the new Bank to be constructed soon, and the personal financial windfall the Bank will provide in the future.

The fans are also used as signs to locate the Bank's entrance. The fan shop acts as the hidden threshold for the characters of the narrative. They also act as a place for the public - including tourists - to buy souvenirs to support and remember their experience at the Olympics, while remaining a cover for the sponsors that are using the Olympics for financial gain. The fans are used to hide the identity of the sponsors who use the hypothetical Bank for money laundering. This illustrates the corruption behind the core usage of the project and how the identity of those involved remain unknown, as the International Olympic Committee is an institution, and the Government of Japan is a body (of people), as oppose to a single, nefarious individual.

The rabbits, slogan and fans are repeated throughout the design which include, signage, pylons, objects, and boundaries. The rabbits and signs are shown, for example, in conjunction to Shinjuku's streetscape in a sea of propaganda and marketing. They are designed into the urban fabric and within the façade of the buildings that represent the front. The pylons are used to close off entrances to the station and to how the privatized section of the Bank. The rabbits become the overarching symbol of the 
To Discover A New Tomorrow

project, as they are added to each sequence, revealing the hypothetical Bank hidden within the existing street fabric of Shinjuku. 


\section{Money Collection}

This drawing displays the moment where money is collected. It begins to change scales to take the viewer through the project and program and to reveal how money is brought into and out of the Bank.

The confetti above transforms into traces of money that disperse through the room. The figures who were hidden in the first set of the drawings are now not using fans to keep their identity hidden but are relying on umbrellas as a cover from the money circulating above; their faces remain hidden. The traces of paper flutter throughout the room, carried by the flow of air produced by the underground subway in the foreground. The lobby, under construction, has scaffolding on the side, as the Bank is assembled and preparing for the influx of corporate and government funds. 


\section{Money Laundering}

This larger scale drawing illustrates the process of money laundering, displaying a scene where trains come in and out of Shinjuku Station - again, paralleling the movement of physical money. Once again, money is seen falling throughout the image to reinforce themes surrounding financial waste.

The drawing consists of scaffolds, advertisements and trains. Scaffolds are drawn to illustrate the construction of the Bank, and the starting process for the Tokyo 2020 Olympics. The play of scale is to illustrate the movement of people using and moving throughout the Bank. 


\section{Vault}

This view was selected in order to take the viewer through the Bank to see the different scales of interactions within the project. The vault is drawn out of cyclical concrete tubes which were components from one of the fencing venues for the Tokyo 2020 Olympics. The purpose of appropriating the steel structures is to indicate that construction elements intended for venues above ground have been workers built some of the parts redirected and used to help build, and reduce the cost of building the underground Bank. The intent is that parts of the Bank are constructed above grade on the Olympic sites to reiterate the Games as a front for the Bank.

The Bank remains under construction, continually expanding because the thesis was written prior to the start of the Games - and because the Games have been postponed. This thesis is therefore in hypothetical real time, expressing what is happening on site at this moment, as oppose to proposing a completed project in the future. 


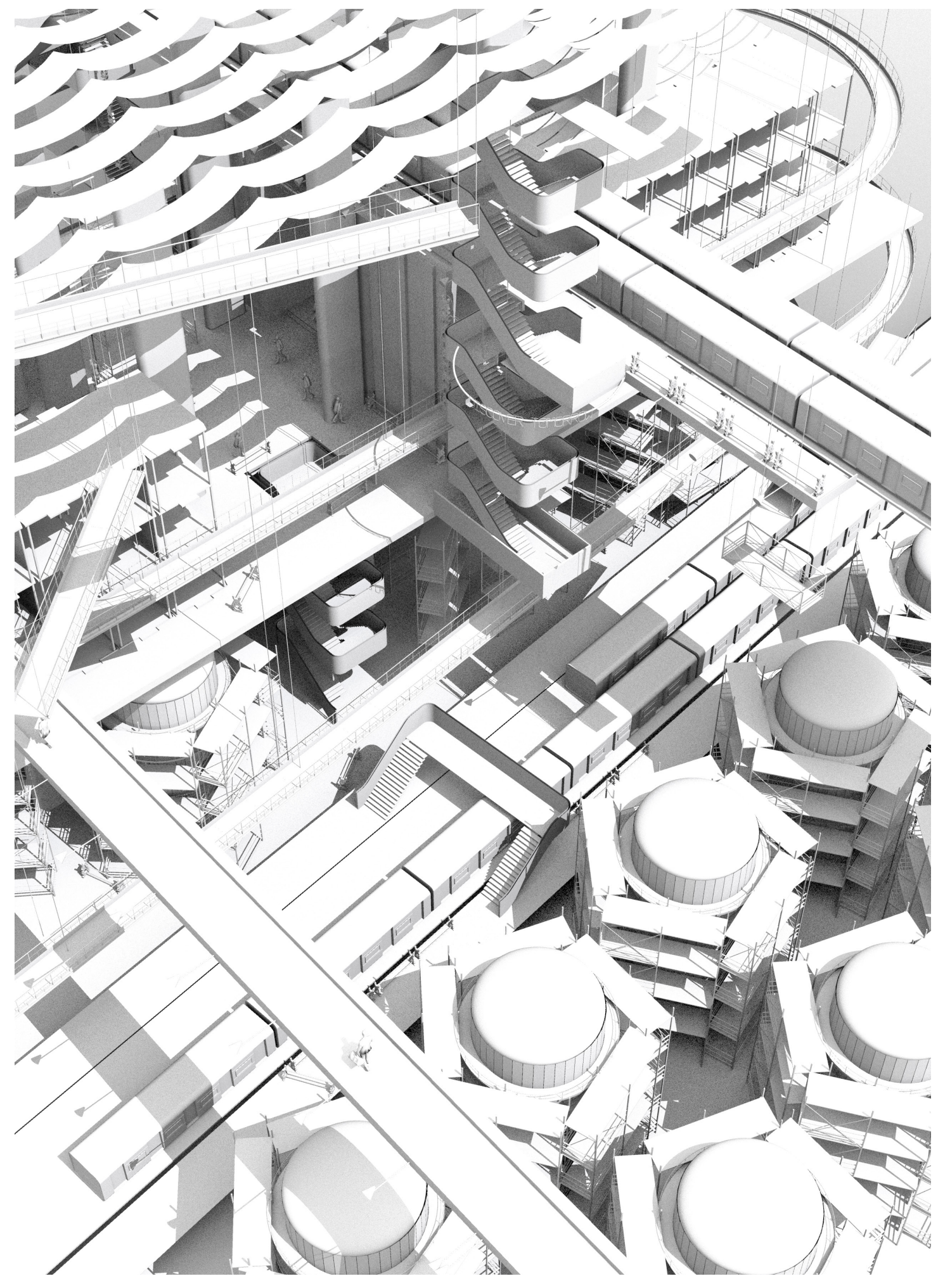


Tokyo 2020

\section{Design Process}

Fig. 21. The process of these drawings included the use of a series of software's and Vault. techniques., including Rhinoceros 6, Illustrator and Photoshop.

Before the drawings began, I went to Tokyo in July and August of 2019 to visit the new Olympic Stadium and Shinjuku Station. I made continual visits to the site each morning, afternoon and the evening and visited other nearby Olympic venues as well as the 1964 Olympic Park. Photographs, sketches and analytical studies were used to observe the flow of people and their interactions. The purpose of this visit was to note the usage of the existing sites and to look for a series of details at large, medium and small scale. Photographs of details such as the developers, construction details, drainage, and infrastructure were recorded. Shinjuku was selected because of the surrounding corporate buildings, and the fact that the district is known as the administrative district which controlled all other districts in Tokyo.

The specific site was chosen to use the existing transportation networks such as buses, trains, and underground to move money in and out of Tokyo. The site is vital for the project to function and uses its existing context to situate the hypothetical program within the fabric of Tokyo. Shinjuku Station has no readily available documentation of floor plans, site plans, or elevations due to security restrictions, therefore these structures are based on observation and documents and drawings available online. 
After the selection of the site, a catalogue of objects was digitally modelled to build a series of assets to use throughout the narrative drawings. These assets included the rabbit pylons, fans, general streetscapes with their visible infrastructures and basic building forms

A schematic design of the Bank was developed to establish the moments and spaces within the Bank, as well as situating the moments when the Bank interacted with the existing context. The design mimicked the underground transportation routes, as well as the flow of traffic from people, buses, subways and trains. Following the schematic design, the moments were broken down into six components: Bank entrance, money collection, money laundering, lobby, shipping and handling, and the vault to give a full narrative and spatial sequence of the project. 
Tokyo 2020 


\section{Drawing Process}

The objects and slogans are modeled in Rhinoceros 6 using basic tools and commands (curve, box, and polylines, for example). To achieve more complex shapes, the drawings use curves and lines to create the outline of certain objects, then made into surfaces with planar surface and extrude surface. After modeling an object in detail, it is then reiterated through the design in signs and pylons. A catalogue of objects is used to make the architecture and streets.

For the final drawings, selected views are illustrate only one action. The drawings carry a lot of information and it is important to maintain clarity and not get lost in what the image is intending to convey; it is meant to be complex, yet clear.

The drawings use the catalogue of modeled components to balance the visual aesthetic of the drawing. It uses these layers to build up, give depth, and complete the narrative of the drawings. This allows the important elements of the project to be examined in greater detail and leaves the rest of the design deliberately (a bit) schematic.

With Illustrator and Photoshop, the drawings are layered with color, textures, and shadows to add detail. Each surface of the drawing is given a color, texture and shadow to create a more immersive image. 
The purpose of the project is to ask larger questions surrounding the Olympics. Therefore, the idea to frame the drawings at a larger scale is to situate a single moment within a larger and more complex set of issues. As each drawing is seen, it illustrates portions of the project to capture the scale of the event. This includes physical elements such as the infrastructure and social occasions such as the celebration towards the games.

The drawings each have a large amount of detail to support the overarching narrative of the project. Each non-generic design used elements from the existing site to use to design and build the Bank. Therefore, the design of the project came from existing elements from the site. It is important to note that the imaginative aspects of the drawings were done to reiterate the idea of the front and of the issues surrounding the Olympics. They are meant to be aesthetically beautiful and playful. It is intended to be a non-generic and site and event specific. The drawings are meant to pull the viewer in, create curiosity and intrigue. It is meant to be deceptive and appear happy, even when it remains dystopian. 


\section{Conclusion}

Cities have been investing large quantities of resources into the Olympic Games. For Tokyo, their intent was to develop competition venues with state-of-the-art technologies, unifying diversity and passing on a legacy to "Discover a New Tomorrow" and to endorse a positive image. ${ }^{26}$ However, there is no evidence suggesting the success or impact of producing long-term imagery enhancements of a city hosting an Olympic Game.

This thesis does not aim to solve the issues surrounding the Olympics but to question and reflect the issues behind the hosting of the Olympic Games. This thesis uses the idea of the front to question the Government of Japan and the International Olympic Committee portraying Tokyo 2020. This thesis hopes to rethink and reconsider the financial burden incurred by hosting such events, and to ask: "who benefits?". This was done by composing a speculative narrative of a hypothetical Bank to illustrate the resources that the Government of Japan is using for the upcoming games.

Like the Summer and Winter Olympic Games, other infrastructural and sport related events including FIFA World Cup, and Euro Cup competitions take place every four years requiring extensive financial resources. FIFA, like the Olympics, invests billions of dollars building stadiums to host thousands of people for a very short time. These productions are designed for short periods to accommodate the influx of people and then are

26 "Tokyo 2020 Action \& Legacy Plan 2016," Legacy Summary. (Accessed September 16, 2019). 
continued to be rebuilt. The significant problems created in this manner have been drastically displayed by the 2016 Summer Games in Rio de Janeiro, Brazil and the 2014 Winter Games in Sochi, Russia as some of the current venues are deteriorating. This is true for other cities as well.

When considering the future of the Olympics and the role of the architect, one must consider the implications of hosting such temporal events. These include the negative and lasting results that come from being the host city. These games use larger financial sums to invest into a city's infrastructure and image, however, continuously result in poorly revitalised areas and lasting economic damage. This damage takes decades to pay for. Therefore, this thesis raises concerns about the decision making of the International Olympic Committee and Governments who continue to bid, host and design such financially intensive games. It is important to pay attention to how the front of the games that is portrayed globally often masks and hides the negative legacies that are continually upheld as a result. 


\section{Postscript}

The final drawings intended to reveal the negative issues behind the Olympics by speculating how the Government of Japan and corporations might mismanage and misuse the financial resources used for the Games by designing a hypothetical Bank to launder money. The Bank is designed at a larger scale to illustrate the quantity of financial funds that are involved. Therefore, the drawings are to inform the public of the scale of spending which typical leads to large financial debt.

The thesis intended to show this negative imagery by revealing a narrative. Each drawing begins exposing the Bank through aerial views and perspectives displaying different sequences of the Bank. Each sequence begins to unfold the narrative showing scenes of characters and figures maneuvering money in and out of the Bank. Each image begins to layer and change scales or functions of the process of money laundering to pull the viewer through the different parts of the Bank. These views are intended to reveal layer by layer, the scale of the corporate corruption of the Olympics through the speculated narrative by bringing the viewer through a dystopia.

The drawings are meant for the public, as they are drawn through external perspectives of the Bank and are meant to be engaged with and provocative, however remain playful. This is to allow an individual to follow along the narrative. At first sight, the drawings may seem positive, however as they begin to inspect the drawings further, to reveal a much darker intent. 
The project does focus on the financial waste of resource therefore draws a dystopia; however, the thesis does acknowledge the Games have had positive economic impacts. These impacts include tax revenues, short term employment and sources of income. ${ }^{27}$ The Games also provide an opportunity to enhance awareness of a host nations city and country which increases publicity and investments in new infrastructure and facilities. ${ }^{28}$ For instance, in Barcelona in 1992, the Games were used as a major regeneration project for the waterfront development which lead to tourist attractions, shopping, dining facilities and improved transportation infrastructure. ${ }^{29}$ The London 2012 Olympics also saw improvements regarding environmental issues such as land and sediment contamination which later was used for the construction of housing and the Olympic Park which had substantial profit. ${ }^{30}$

In conclusion, there are positive benefits including economic gain from hosting however the thesis is aimed to counter brand the existing promotional aesthetic of the Olympics, as the Governments and International Olympic Committee often neglect and do not further investigate the cultural and social impact of the Games.

${ }^{27}$ Brent W. Ritchie, Richard Shipway, Bethany Cleeve, "Resident Perceptions of Mega-Sporting Events: A Non-Host City Perspective of the 2012 London Olympic Games," Journal of Sport \& Tourism, 14. (2009).

28 Ibid.

$29 \mathrm{lbid}$.

${ }^{30}$ Deyi Hou, Abir Al-Tabbaa, Peter Guthrie, Jan Hellings, and Qingbao Gu. "Using a hybrid LCA method to evaluate the sustainability of sediment remediation at the London Olympic Park." Journal of cleaner production, 83 (2014): 87-95. 


\section{References}

Burton, Rick, "Olympic Games Host City Marketing: An Exploration of Expectations and Outcomes", Sport Marketing Quarterly, no. 37 (2003).

CJ, Lim, Inhabitable Infrastructures: Science fiction or urban fiction?. New York. Routledge, 2017.

Darcy, Simon, and Tracy Taylor. "Managing olympic venues," In Managing the Olympics, 2013.

Davis, John. The Olympic Games Effect: How Sports Marketing Builds Strong Brands. John Wiley \& Songs, 2008.

Dornhege, Mareike. "Shinjuku Ward Guide: Tokyo's Beating Neon Heart." REthink Tokyo-Real Estate Information for Buyers and Investors, April 2, 2019. https://www.rethinktokyo.com/shinjuku-area-guide (accessed September 30, 2019).

Featherstone, Mike, and Tomoko Tamari. "Olympic Games in Japan and East Asia: Images and Legacies: An Introduction." International Journal of Japanese Sociology 28, no. 1 (2019): 3-10.

Guillaume Bodet, and James Andrew Kenyon, "Exploring the domestic relationship between mega-events and destination image: The image impact of hosting the 
2012 Olympic Games for the city of London", Sports Management Review, (2018): 232-249.

Gallego, Viviana, Hiroshi Nishiura, Ranjit Sah, and Alfonso J. Rodriguez-Morales. "The COVID-19 outbreak and implications for the Tokyo 2020 Summer Olympic Games." Trav Med Infect Dis 101604 (2020).

Hou, Deyi, Abir Al-Tabbaa, Peter Guthrie, Jan Hellings, and Qingbao Gu. "Using a hybrid LCA method to evaluate the sustainability of sediment remediation at the London Olympic Park." Journal of cleaner production, 83 (2014): 87-95.

Kaufmann, Emil. "Étienne-Louis Boullée." The Art Bulletin 21, no. 3 (2012): 213-27.

Lai, Jimenez. Citizens of No Place: An Architectural Graphic Novel. New York: Princeton Architectural Press, 2012.

Lim, CJ, Liu, Ed. Short Stories: London in two-and-a-half dimensions. Oxfordshire: Routledge, 2011.

Morrow, Richard. "Tokyo's Costly Olympic Win." Asia. (2013).

Ritchie, Brent W., Shipway, Richard, Cleeve, Bethany. "Resident Perceptions of MegaSporting Events: A Non-Host City Perspective of the 2012 London Olympic Games," Journal of Sport \& Tourism, 14. (2009).

Thronley, Andy. "The 2012 London Olympics. What is Legacy?." Journal of Policy Research in Tourism, Leisure and Events, (2012): 207-297.

"Tokyo 2020 Action \& Legacy Plan 2016." Legacy Summary. https://tokyo2020.org/en/games/legacy/items/legacy-summary_EN.pdf (September 16, 2019). 
To Discover A New Tomorrow

"Tokyo 2020 on Track to Deliver Unifying Olympic Games." Targeted News Service (Washington, D.C.), 2018.

"Tokyo 2020." Tokyo 2020, The Tokyo Organising Committee of the Olympic and Paralympic Games. https://tokyo2020.org/en/. (accessed March 31, 2020).

Walker, John. "Visionary Architecture." Glossary of Art, Architecture \& Design since 1945, n.d. Accessed October 28, 2019.

Williams, David. "Tokyo 2020: a legacy or lethargy for tourism?." Josai International University, Faculty of Tourism Bulletin 25, no. 6 (2017): 51-66. 
Tokyo 2020 